Western University

Scholarship@Western

Economic Policy Research Institute. EPRI Working

Papers

Economics Working Papers Archive

2005

2005-10 Welfare Reforms and Consumption among Single Mother Households: Evidence from Canadian Provinces

Matthew Brzozowski

Follow this and additional works at: https://ir.lib.uwo.ca/economicsepri_wp

Part of the Economics Commons

Citation of this paper:

Brzozowski, Matthew. "2005-10 Welfare Reforms and Consumption among Single Mother Households: Evidence from Canadian Provinces." Economic Policy Research Institute. EPRI Working Papers, 2005-10. London, ON: Department of Economics, University of Western Ontario (2005). 


\title{
Welfare Reforms and Consumption Among Single Mother Households: Evidence from Canadian Provinces
}

\author{
by
}

\author{
Matthew Brzozowski
}

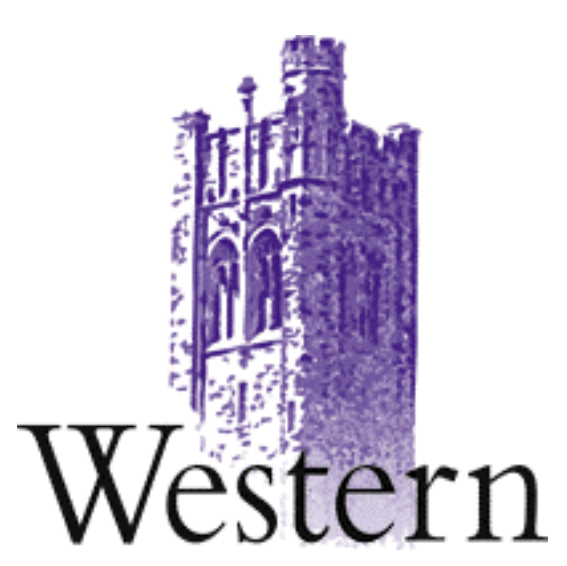

\section{RBC Financial Group Economic Policy Research Institute EPRI Working Paper Series}

\author{
Department of Economics \\ Department of Political Science \\ Social Science Centre \\ The University of Western Ontario \\ London, Ontario, N6A 5C2

\section{Canada}

This working paper is available as a downloadable pdf file on our website http://www.ssc.uwo.ca/economics/centres/epri/ 


\title{
Welfare Reforms and Consumption among Single Mother Households: Evidence from Canadian Provinces.
}

\author{
Matthew Brzozowski ${ }^{* *}$ \\ Department of Economics, \\ The University of Western Ontario
}

November 2005

DRAFT

\begin{abstract}
:
This paper evaluates the impact of the 1995-1998 Ontario welfare reforms on the consumption among single mothers. Because welfare is a provincial responsibility in Canada, this study is able to consider the effects of the welfare reforms in Ontario, in comparison with other Canadian jurisdictions at the same time. By utilizing a difference in difference design I compare the changes in the consumption levels among Ontario single mothers to changes in the consumption levels among three distinct segments of Canadian population. The comparison with demographically identical groups under different provincial administrations and the implementation of difference in difference propensity score matching estimates sets my approach apart from previous similar work. The results indicate an initial decrease in the relative consumption levels among Ontario single mothers. This negative policy impact is not present in the long-term results.
\end{abstract}

JEL classifications: D310, I310, I380

Key words: Welfare Reform, Difference in Difference, Lone Mother

\footnotetext{
* I would like to thank my supervisor, Thomas Crossley, as well as Martin Dooley and Michael Veall for their insightful comments and support during the project. Participants at McMaster University and The University of Western Ontario seminars and at the Canadian Economic Association meetings also contributed helpful comments. Special thanks go to Lonnie Magee for his help with the Inverse Hyperbolic Sine transformation and to Vincent Hildebrand for his help with the propensity score matching estimators. All errors are my own.

** Matthew Brzozowski is a lecturer at the Department of Economics at The University of Western Ontario. He can be reached at: (519) 661-2111 Ext. 85384, Fax: (519) 661-3666 mbrzozow@uwo.ca . This paper is one of the chapters of author's doctoral dissertation.
} 


\section{Introduction.}

The effects of welfare reforms on living standards are of considerable importance to policy makers and researchers. Major changes to welfare policy have both equity and efficiency consequences. In the second half of the 1990’s, Canadians experienced significant changes in the rules governing eligibility for social assistance ${ }^{1}$ and in the levels of benefits. Welfare reforms were most extensive in the province of Ontario where they included both the $21 \%$ cut in benefit levels and the tightening of the eligibility rules. The segment of the population that is most dependent on social assistance, and thus most affected by changes to the welfare code, is single mothers. They account for $12 \%$ of family heads [Statistics Canada, 1996] and 30\% of welfare caseload [National Council of Welfare, 1998]. This paper evaluates the impact of the 1995-1998 Ontario welfare reforms on the consumption levels among single mothers.

I expand on the methodology adopted by Meyer and Sullivan [2004] to examine how different measures of consumption vary in response to transfer income shocks. They look at the 1996 Temporary Assistance to Needy Families (TANF) reforms in the United States. They utilize a difference in difference study design similar to that described in the following sections. Using a traditional natural experiment framework, the authors compare the 'before policy’ and 'after policy’ consumption estimates for US single mothers relative to estimates for childless single women and married couples with children. Partly as a result of the nationwide nature of the US reforms, Meyer and

\footnotetext{
1 The terms "welfare” and "social assistance” (which is how welfare is often referred to in Canada) are used interchangeably in this paper.
} 
Sullivan did not differentiate between jurisdictions and, as such, did not compare single mothers covered by policy changes to single mothers experiencing policy stability.

Meyer and Sullivan find evidence of a slight relative improvement in the consumption levels among single mothers. Their results should not appear counterintuitive. One could expect that a considerable 'tightening' of the welfare system should have negatively affected the group traditionally dependent on social support. However, those changes would be fully reflected by a fall in non-measurable utility. The changes in the US welfare code have made the participation in the workforce more attractive relative to social assistance, and thus, through well-understood, labour-leisure, substitution effects have resulted in an increase in average consumption.

I utilize Canadian 1986 - 2001 household expenditure surveys and implement a difference in difference experimental design. In it I compare the changes in the consumption levels among Ontario households headed by single mothers to changes in the consumption levels among three distinct family types. These are the Ontario single childless women, Ontario married couples with children, and Quebec and British Columbia single mothers. The first two family types are analogues to those used by Meyer and Sullivan. The ability to use the third family type, and thus to take an advantage of variations in provincial policy, sets my approach apart from their study. The suitability of each of these groups for the purpose of control in the natural experiment is discussed in the following section.

Recent related Canadian literature evaluates welfare reforms from the perspective of welfare take-up, spell-duration and welfare-to-work related questions [Beaulieu et al 2005, Lemieux and Milligan 2004, Milligan and Stabile 2004, Fortin et al 2004, Green 
and Warburton 2004, Roy 2004, Sceviour and Finnie 2004, Dooley et al 2000]. To my knowledge this study represents a first attempt to move beyond those issues and to evaluate the effects of Canadian welfare reforms by focusing directly on household consumption.

Total family consumption is a useful indicator of economic well-being. While exact data on consumption is seldom available, it has become standard practice to use estimates of the family budget constraint or total family expenditure. I use reported estimates of individual family total expenditure as proxy measures for consumption, as did Meyer and Sullivan [2004]. As an alternative measure of consumption I also use net income after taxes ${ }^{2}$, I find that when total expenditure or total after tax family income are used as measures of family consumption, there is considerable evidence of a temporary fall in the relative consumption levels among Ontario single mothers. I also find evidence of no long-term policy effects. This lack of long-term consequences suggests a subsequent recovery from the initial drop. When Quebec and B.C. single mothers are used for comparison the results are most consistent across various methods and specifications. These results also indicate significant between period variation in consumption levels among single mothers.

The remainder of the paper is composed as follows: Section 2 provides an outline of the relevant policy reforms; Section 3 describes the data and the sample selection methods; Section 4 outlines the methodology; Section 5 discusses the key results; Section 6 concludes.

\footnotetext{
${ }^{2}$ Additionally in the appendix available online, I explore several components of the budget constraint. These are social transfer family income, wage income and change in assets.
} 


\section{Outline of the 1995-1998 policy changes: provincial Welfare Reforms and the introduction of the National Child Benefit program.}

Ontario, Quebec and British Columbia are the three most populous Canadian provinces, and together they include about three out of four Canadians. The majority of Canadian single mothers and Canadian welfare recipients also inhabit these provinces. The relative stability of Quebec and British Columbia welfare laws, during the 19951998 period allows for (at least partial) detection of Ontario specific outcomes in relation to nation-wide trends.

The years from 1995 to 1998 were marked by considerable reductions in the number of welfare recipients within each of the provinces under consideration. Table 1 illustrates this decline. According to the Canadian Council of Social Development [1995, 1998], the number of Ontario welfare recipients decreased by $19 \%$ during this period. The proportional fall in British Columbia was 21\%, while the fall in Quebec was only $10 \%$.

A difference in difference experimental design allows for observing the magnitude of the relative changes in the dependent variable without fully understanding the causality behind those changes. However, in order to interpret the relationships implied by the observed results, one needs to possess a basic understanding of the policy changes underlying the experiment. Both federal and provincial governments initiated these changes. The relevant reforms can be grouped into (i) welfare system related reforms and (ii) National Child Benefit related reforms. Welfare program reforms were provincial initiatives and were typically designed to make dependence on social assistance less 
attractive in relation to paid employment. The National Child Benefit (NCB) was a joint federal-provincial program that offered new subsidies to low-income families with children and, in most provinces, also made participation in the workforce more attractive relative to welfare. What follows is a brief description of these policy changes indicating how they provide a suitable natural experiment.

\section{Welfare Reforms in Ontario, Quebec and B.C.:}

Ontario enacted the most extensive welfare reforms of all Canadian provinces in the 1990's. In 1995, welfare benefit levels were cut by 21 percent $^{3}$. The Ontario Works Act was passed in 1996 and implemented in 1998. ${ }^{4}$ Ontario Works was implemented gradually, but the objective of the program remained constant. Its overriding focus is to redirect people from permanent dependence on welfare towards the shortest route to full employment. Regulations regarding eligibility for benefits were changed in order to make dependence on welfare less attractive relatively to paid employment. Couples living in common-law relationships were no longer able to claim sole support for the purpose of increased eligibility. Participation in academic upgrading, retraining and job-search related activities, was no longer an option but a requirement for welfare eligibility. The grounds for exemptions from participation in the above activities were also increasingly restricted during the implementation period. ${ }^{5}$ When Ontario Works was fully implemented, the only groups permanently exempted from participation were seniors and

\footnotetext{
${ }^{3}$ Even after cuts the benefit levels remained the highest of all Canadian provinces when not adjusted for province specific cost of living.

${ }^{4}$ Social Assistance Reform Act.

${ }^{5}$ For a more detailed overview consult Ontario Works Program Overview 2001.
} 
the disabled. ${ }^{6}$ This general participation requirement was the most important feature distinguishing the Ontario reforms from the policies adopted in Quebec and B.C.

In 1998, single mothers lost their previously automatically awarded exemption from participation in job search or training. In order to remain eligible for benefits, they too were required to demonstrate their efforts to move to paid employment. We can therefore divide the years under consideration into two separate policy periods: (i) the early (pre 1998) reform period of benefit cuts, initial reforms and exemptions, and (ii) the late (post 1998) reform, period after all the reforms had been implemented and exemptions tightened.

By comparison to Ontario, the province of Quebec experienced only minor reforms to welfare policy during the 1995-98 period. The policies adopted in Quebec emphasized transition to employment by gradual rather than by fastest possible means. The transition was to be achieved through training and skill improving programs. Benefit levels were not reduced and paid employment was to become more attractive to welfare recipients by means of improvements to the situation of low-income workers. Further changes, legislated in 1999 and after, proceeded in an unchanged spirit: the number of services offered seemed to increase steadily but participation in these programs was not a mandatory requirement for eligibility for social support. [The National Study of Welfare to Work Programs, Phase 1 and Phase 2, Quebec]

British Columbia also adopted a series of welfare reforms during the second half of the 1990s. In 1996: the BC Benefits (Youth Works) Act and the BC Benefits (Income

\footnotetext{
${ }^{6}$ Temporary exemptions (typically of three month duration) could be granted only on the following grounds (i) having a temporary medical condition, (ii) lacking of an appropriate daycare, (iii) caring for the disabled, (iv) caring for family members suffering from a documented medical condition, (v) caring for seniors with documented special needs, (vi) requiring pregnancy/parental leave and (vii) being a single parent caring for a pre-school age child.
} 
Assistance) Act were passed. The first of the acts was aimed specifically at the reduction of unemployment among youth (age 19-24). According to its provisions, young adults unable to support themselves were eligible for social assistance under conditions similar to those adopted by Ontario for most welfare recipients. In B.C. these young welfare recipients had to actively seek employment and to participate in job training. In return they were offered an allowance and priority placement both in skills training programs and in employment. For the rest of B.C.'s population, however, participation in job search or training was not an explicit condition for welfare eligibility. [The National Study of Welfare to Work Programs, Phase 1 and Phase 2, British Columbia]

\section{National Child Benefit $^{7}$}

The National Child Benefit (NCB) is a joint federal-provincial program designed to provide financial aid to children of lower-income families. NCB went into effect in 1998. In Ontario, B.C. and in a number of other provinces the program encourages working families to remain in the workforce [Milligan and Stabile 2004]. In these provinces benefits provided by NCB are not available to welfare recipients and thus they provide an additional incentive for continued participation in paid employment. In Ontario provincial social assistance benefit levels were reduced by the amount provided federally under the NCB program. These "saved" provincial funds are then redirected towards investments designed to improve the well-being of low-income children. In July 1998, Ontario introduced the Ontario Child Care Supplement for Working Families. This program provides for annual benefits of up to $\$ 1020$ per child to cover the child-care expenses of families with earnings above $\$ 5000$ (the benefits are reduced if earnings

\footnotetext{
${ }^{7}$ National Child Benefit Progress Report 1999, Appendix 1.
} 
exceed $\$ 20$ 000). The families eligible are (i) those in which one of the parents is working and the other takes care of children below the age of seven, and (ii) one of the parents is a student or trainee and the family incurs child-care expenses. Additional funds (about \$200 annually) were also made available specifically to working single parents. Ontario municipalities pay about $20 \%$ of the costs of social assistance and hence some of the funds freed by NCB are reinvested into various local programs.

British Columbia had a provincial program similar to the NCB as early as 1996 the B.C. Family Bonus. In 1998, NCB benefits were integrated into this provincial child benefit transfer program. Because NCB supplemented the provincial program, the "saved" funds were redirected mainly towards the B.C. Earned Income Benefit program aimed at reducing the disincentives faced by low-income families reentering employment. In B.C., just like in Ontario, NCB provided incentives to leave social assistance and to enter employment [Pennock 2003].

The Quebec government has not officially joined the NCB initiative. Quebec families receive federal NCB transfers that are not integrated with the provincial system and are not contingent on entering or continuing employment [Milligan and Stabile 2004]. Further, in 1997 the province of Quebec introduced, the well-publicized, fivedollars-per-day childcare program that provides universally subsidized childcare to Quebec families. ${ }^{8}$ The eligibility for this subsidy is not contingent upon labor force participation.

\footnotetext{
${ }^{8}$ This program has limited average impact on the standards of living among single mother households. As outlined by Lefebvre [2004] the majority of Quebec children registered in subsidized childcare are those from higher income families (with incomes above \$40 000). Single mother households typically fall into lower income brackets and are consistently underrepresented among those enrolled in the program. Baker et al [2005] further explain that lower income Quebec families are eligible for a significant childcare subsidy that they have to forgo in order to be eligible for the $\$ 5 /$ day childcare. For families with incomes $\$ 20000$ the value of this subsidy exceeds the value of the subsidy under the $\$ 5 /$ day alternative.
} 


\section{Control Group Suitability.}

The Ontario welfare reforms and the National Child Benefit initiative should have similar consequences for single mothers - the attractiveness of paid employment relative to welfare should have increased as a result of both reforms. Lemieux and Milligan [2004] point out that the eligibility for welfare benefits of Canadian singles and nonparents is one of the features distinguishing the Canadian welfare rules from the US system. It can thus be argued that, unlike in US, single childless women and married couples with children were also affected by the Ontario welfare reforms. Married couples with children were also affected by the NCB reforms. The effects of both the welfare and the NCB reforms should be qualitatively similar for all affected groups. Also, single mothers in B.C. (but not in Quebec) should be affected by the introduction of NCB in a manner similar to Ontario single mothers.

Sceviour and Finnie [2004] show that Canadian single mothers rely on welfare to a much higher extent than single childless adults or married couples with children.

Sceviour and Finnie also show that, over the 1995 to 2000 period, the likelihood of an Ontario single mother receiving social assistance changed considerably more than it did for a single woman or a married couple with children. ${ }^{9}$ This low vulnerability to welfare policy changes (relative to single mothers) makes single childless women and married couples with children suitable as control groups in the experiment.

\footnotetext{
Consequently Baker at al demonstrate that the average subsidy per single parent family remained largely stable between 1992 and 2002.

${ }^{9}$ Sceviour and Finnie [2004] examine trends in incidence of social assistance over the reform period. They show that between 1995 and 2000 the proportion of Canadian single mothers relying on social assistance fell from $50.1 \%$ to $33.6 \%$. At the same time the social assistance rates for Canadian singles fell from $20.1 \%$ to $15.9 \%$ and the rates for couples with children fell from $8.9 \%$ to $5.9 \%$. Within Ontario, single mother social assistance rates fell from 56.1\% in 1995 to 33.2\% in 2000. The rates for Ontario singles and Ontario married couples with children fell from $20.9 \%$ to $14.1 \%$ and from $10.3 \%$ to $5.6 \%$ respectively. Finally, between 1995 and 2000, social assistance rates for single mothers in Quebec fell from 45.7\% to 32.0\% and in B.C. they fell from 52.7 to $37.1 \%$.
} 
The partial treatments affecting the control groups are not equally shared across all three groups. Quebec and B.C. single mothers are immune to Ontario specific effects. Similarly, any province specific trends present in Quebec and B.C. will be absent in Ontario. Due to low intensity of welfare dependence of Ontario control groups, they are much less likely to be affected by the changes to welfare code than the single mothers. Similarly, the relatively low intensity of policy reforms in Quebec and B.C. is likely to have little comparable impact on the consumption of Quebec and B.C. single mothers control group. In this paper the results are stable across control groups that do not share common treatments. This suggests a presence of a consistent effect of Ontario welfare reforms on the province's single mothers, even if various other treatment effects cannot be completely eliminated from the control groups.

Another way to argue for the suitability of the control groups is to agree that the second half of 1990s was a time of widespread welfare reforms all over Canada. Policy changes affecting most of Canadians were bound to happen. Thus the effects of Ontario reforms in the context of a difference in difference natural experiment should not be formed around an empirically irrelevant counterfactual of no-policy change. The results relative to other jurisdictions can be interpreted as formed around a counterfactual of less extensive policy reforms. Similarly the results relative to other Ontario based control groups can be thought of as addressing a counterfactual of less effective policy targeting. 


\section{Data.}

The data for this paper come from the Canadian Family Expenditure Survey (FAMEX) and its subsequent replacement, the Survey of Household Spending (SHS). Both surveys are based on the same Statistics Canada labor force sampling frame and use the same weighting system. They cover the same population and the same geographic areas. Finally, both surveys include a number of identically or nearly identically defined variables. As such, merging the surveys for our purposes is a relatively straightforward matter. $^{10}$

I divide the time frame into three periods. Period one includes the years before the 1995 benefit reduction. From this period I use the 1982, 1986 and 1992 surveys. The rest of the available FAMEX surveys have been dropped for the following reasons: The 1984 and 1990 surveys cover only families living in certain urban areas. It is generally accepted that the cost of obtaining a given standard of living varies between urban and rural areas and hence an inclusion of these years into the analysis would bias the results. It might not be possible to distinguish the effect of particular policies from the effect of living in an urban area. The 1978 survey was dropped because of an inability to match the key variables with the rest of the data. The 1969 and 1974 surveys were deemed irrelevant.

Period two, the early reform period, refers to the years 1996, 1997 and 1998, the first years after the welfare cuts. These years include the period of gradual implementation of Ontario Works, the narrowing of exemptions from participation in job search and training related - activities, and the introduction of the National Child Benefit.

\footnotetext{
${ }^{10}$ For more details consult Statistics Canada. (2000)
} 
The 1996 survey is the final FAMEX survey and the following two are the first SHS surveys.

The final period, the late reform period, includes all available SHS data after 1998: i.e. the 1999, 2000 and 2001 surveys. It covers the time period when all the Ontario welfare reforms were fully implemented. This division into three time periods makes it possible to construct a two stage difference in difference experimental framework in which the immediate transition effects of policy (early reform period) are isolated from the effects after adjustment (late reform period).

The estimated sample was selected using the following guidelines. With the exception of the 1996 survey, only households headed by persons of age 18 to 64 were included. The demographic information in the 1996 survey is inconsistent with the rest of the surveys. For that year only, households headed by individuals who were 16 or 17 years of age were included. Also, in order to maintain continuity of age definitions between the FAMEX and SHS surveys, all reported age answers were bottom-coded at 25.

The treatment and control groups were selected as follows: single mother households, for both treatment (Ontario) and control (Quebec and B.C.) groups, were defined as those headed by a non-married female age 18-64, including no other persons of age 18-64, at least one child of age 15 or younger, and no persons of age 65 and over. Married couples with children were defined as two opposite sex, married people age 1864, at least one child of age 15 or younger, and no persons of age 65 and over. The selection of single women living alone was a trivial process. 
The above specification criteria for sample selection are not ideal, and are dictated by the demographic information available. One shortcoming is that only those single mothers who were living in households with no other adults are included. Fortunately, as Dooley [1999] points out, close to 90\% of Canadian single mothers with young children reside in single adult households. I was also not able to exclude students, whose consumption levels can be interpreted as a consequence of their investment strategy and, as such, do not make suitable control groups. These shortcomings have potential consequences for interpreting labor supply decisions or for interpreting relative magnitudes of various budget constraint components.

\section{Methodology:}

The results discussed in the next section were produced in three stages. First, 'raw' difference in difference estimates were created by a way of simple comparisons of the means within the traditional 'before/after treatment/control' four-cell framework. Second, I followed the methodology adopted by Meyer and Sullivan [2004] and introduced additional information using regression adjusted difference in difference analysis. The incorporation of the demographic details allows separating the mean changes in consumption resulting from policy effects from those resulting from the changes in the characteristics of Ontario single mothers and the relevant control groups. Third, I applied propensity score matching adjusted difference in difference methodology to further account for differences between treatment and control groups. 
In order to account for the household economics of scale, all of the results were estimated on per household and per household member basis. First, separate estimation routines were run with various measures of household consumption as dependent variables. Second, each of these consumption measures was divided by the household size and then otherwise identical estimation routines were performed again. I was therefore able to interpret the results as accounting for the upper and the lower bounds of households' economies of scale (with the true result being somewhere in between). The differences in results between per household and per household member estimates are negligible. ${ }^{11}$ For ease of interpretation all the results are presented on a per household member basis.

Meyer and Sullivan point out that expenditure is typically a more reliable measure of consumption (and hence a better indicator of the material standard of living) than income is. I have therefore constructed a measure of total expenditures on all goods and services that cannot be considered investments. I use the sum of expenditures on a series of composite commodities. The composite commodities included in this measure are food purchased from stores, food purchased at restaurants, shelter, household operation, furnishings, car purchase, gasoline, car operation, public transit, personal care services and supplies, alcohol and tobacco, recreation and clothing. I have also used after-tax income as another consumption measure. ${ }^{12}$

The 1992-base Consumer Price Index (CPI) has been used to deflate all expenditure and income measures. Alternatives to the national CPI include a budget-

\footnotetext{
${ }^{11}$ Similarly Meyer and Sullivan [2004] have also found that the choice of the equivalence scale was of minor consequence.

${ }^{12}$ Attempts to use the following three components of budget constraint: (i) government transfer income, (ii) wage income, and (iii) yearly change in assets, as dependent variables are not presented here but are discussed in the appendix that is available from the author.
} 
share-weighted mean of several commodity-specific price indexes, and province-specific deflators. Sensitivity tests revealed no significant differences across these alternative specifications of the deflator.

For the regression adjusted difference in difference approach I use the following model to compare responses of Ontario single mothers to those of single mothers in Quebec and B.C.

$$
f\left(c_{i}\right)=\beta_{1}+(\text { dOntariodper })^{\prime} \beta_{2}+\text { dOntario' } \beta_{3}+\text { dper }^{\prime} \beta_{4}+X^{\prime} \beta_{5}
$$

where $f\left(c_{i}\right)$ is a function measuring per capita consumption by household $i$, dOntario is an Ontario dummy, dper is a vector of time period dummies ${ }^{13}$, dOntariodper is the interaction term formed by multiplying the Ontario dummy by the time period dummies, and $X$ is a vector of demographics. ${ }^{14}$

The regression model used to compare the consumption levels among Ontario single mothers to the consumption levels among Ontario unmarried childless women or to those among Ontario married couples with children is the following:

$$
f\left(c_{i}\right)=\beta_{1}+(\text { SMdper })^{\prime} \beta_{2}+S M^{\prime} \beta_{3}+d p e r^{\prime} \beta_{4}+X^{\prime} \beta_{5}
$$

where $S M$ is a single mother dummy and SMdper is the is the single mother time period interaction term.

The effects of the experiment are the coefficients on dOntariodper or on SMdper (the treatment group-time period interaction terms) that capture the difference in

\footnotetext{
${ }^{13}$ There are two time period dummies. The first is set equal to 1 for observations recoded during the early reform and 0 otherwise and the second is set equal to 1 for observations recoded during the late reform period and 0 otherwise. The pre-reform period is set as base.

${ }^{14}$ Unfortunately, the only three demographic characteristics that could be successfully traced across all the survey years are the household size, the age of head of household and the dummy variable set to 1 for observations recorded in cities above 100000 residents. The lack of any education level related variables within the Survey of Household Spending precluded the option of focusing on low educated single mothers (like Meyer and Sullivan 2004).
} 
difference policy effects on the Ontario single mothers. The treatment group dummy

accounts for the effect of being an Ontario single mother on the predicted consumption

levels of households. The time period dummies account for the general time trend effects, and the pre-policy period is set as base. The interaction terms capture the effects specific to single mothers in respective time periods, and, as such, account for the differences in the predicted consumption levels between Ontario single mothers and either of the control groups in each of the two policy time periods.

I use one control group at a time and drop the other control groups out of the estimation. Alternative geographic specifications for equation (1) were used, as were control groups made up exclusively of Quebec single mothers, or exclusively of B.C single mothers. The sensitivity of equation (1) results to using either of these provinces alone is marginal ${ }^{15}$.

The transformation chosen for the dependent variable is $\sinh ^{-1}(\theta c) / \theta$ which is the inverse hyperbolic sine proposed by Burbidge et al (1988). $\theta$ is a parameter set equal to one (as in Browning and Crossley 2004) and $c$ is the measure of consumption. This transformation handles large positive values in a manner similar to logarithms, but, unlike logs, it allows for admitting non-positive values. ${ }^{16}$

After the 'raw' and regression adjusted approaches, the third type of analysis is propensity score matching adjusted difference in difference. Matching estimators assign

\footnotetext{
${ }^{15}$ Similarly, if equation 1 is estimated using all of Canada's non-Ontario single mothers as controls, the general conclusion of the difference in difference results holds across all specifications. What seems to vary is the level of significance.

${ }^{16}$ This property is especially practical when the components of the budget constraint such as the government transfer income, the wage income, or the yearly change in assets and liabilities are used. These, measures are positive for only a fraction of a population and, as such, could not be properly accounted for in a traditional log linear framework. These results are discussed in the, available online, appendix. For net income and expenditure regressions which transform always positive dependent variable the results from regressions using inverse hyperbolic sine of the dependent variable produce marginal effects nearly identical to their log linear alternatives.
} 
each member of the treatment group to a member(s) in the control group who exhibits similar observable characteristics. Conditional on those characteristics, potential experimental outcomes are assumed independent of treatment or control group membership. Only those members of the treatment group and the control group for whom a suitable match can be found are included in the analysis. In other words, matching adjusted difference in difference estimators compare the before and after differences between treatment and control groups only over the so-called common support range. ${ }^{17}$

The larger the number of the characteristics that determine the common support, the more complex and computationally intensive is the resulting matching process. Fortunately, Rosenbaum and Rubin (1983) prove that matching can be obtained by pairing treatment and control subjects according to their propensity scores obtained from a parametric model that estimates the conditional probability of belonging to an experimental treatment group. Logistic regression is used for this purpose.

Matching routines implemented for this paper are conducted as follows. First, propensity scores from a logistic regression on participation within the program (i.e. on being an Ontario single mother) are obtained. Those regressions utilize the same demographic characteristics as the regressions in stage two of the analysis. In each case Ontario single mothers are matched to members of one control group while the other two control groups are dropped from the analysis. Second, I perform the matching using the psmatch2 STATA procedure developed by Leuven and Sianesi (2003). Kernel matching is utilized instead of the typical, single, nearest neighbor matching. ${ }^{18}$ This procedure matches each of the members in a treatment group who fall within the common support

\footnotetext{
${ }^{17}$ For an in depth summary of different matching estimators consult Smith and Todd (2003).

${ }^{18}$ In the case of nearest neighbor matching, the presence of observations with identical propensity score values can cause the sorting order of the data to affect the results.
} 
region to a weighted average of several subjects within the control group. While the psmatch2 procedure allows for several different choices of Kernel weighting functions, they all produce very similar results and so the default Epanechnikov Kernel specification has been used. ${ }^{19}$

\section{Results.}

\subsection{Summary statistics and 'Raw' difference in difference results.}

Tables 2 and 3 offer an overview of the data. Table 2 provides sample sizes, represented population sizes, and per capita weighted means of various components of the budget constraint. Table 3 further provides a by source of income breakdown of the budget constraint. The results in tables 2 and 3 are presented for every year of the data, for each of the groups analyzed. Several trends appear for both total expenditure and total net income. First, in 1992 and earlier, Ontario single mothers enjoyed higher per capita income and expenditures levels than single mothers in Quebec and B.C. That relationship was reversed with the introduction of welfare reforms in Ontario in 1995. It was not until 2000 that Ontario single mothers again had higher levels of income and expenditure.

Second, average transfer income is only a fraction of the average wage income for each group and year. This is consistent with the government transfer income being designed to provide only a minimal sustainable standard of living. Between 90 to 100 percent of Ontario single mothers reported positive government transfer income, but this

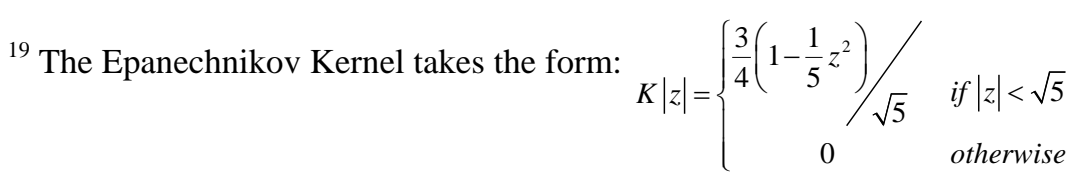


represents only a fraction of net income on average. In the pre reform period between 60 and 72 percent of Ontario single mothers reported positive wage income, but this figure dropped by about 10 percent during the early policy period. This last finding is especially interesting, given the goal of Ontario policy reform, and the rising employment rates of Quebec and B.C. single mothers during the same period. Table 3 shows that it was not until the post implementation period that the employment rates of Ontario single mothers increased and eventually surpassed the levels in other provinces.

A pair of probit regressions for labor force participation was run to further investigate the employment decisions of Ontario single mothers. Two distinct dependent variables were used: 'participated in wage employment at any time during the reference year' and 'participated in wage employment for all of the 52 weeks of the reference year ${ }^{20}$ The results in table 4 indicate that during the implementation period, Ontario single mothers experienced a decrease in their labor force participation rates relative to Quebec and B.C. single mothers. These results also indicate that, relative to the other two control groups, Ontario single mothers have experienced a considerable increase, of up to 20 percent, in labor force participation during the post implementation period.

Table 3 illustrates another feature, more consistent with the policy timing. This is a decrease in the incidence of reported positive transfer income among Ontario married couples with children starting in 1996. The first period of Ontario welfare reforms is associated with a decrease of up to 30 percent in the proportion of Ontario married couples with children receiving any transfer income at all. It does appear that the Ontario welfare reforms had the immediate effect intended by policymakers. The implementation

\footnotetext{
${ }^{20}$ Alternative specifications controlling for the differences between part time and full time employment were also tried. These added little extra information.
} 
of the 1998 National Child Benefit Act, however, had only slight, if any, effects on either the incidence, or the amount of transfer income received. No similar pattern can be observed in the behavior of single childless women in Ontario.

Most of the survey respondents reported changes in assets and liabilities, but on average these were small relative to other measures. The data do imply however that Ontario single mothers tend to dissave between \$300 to \$700 more than Quebec and B.C. single mothers in almost every surveyed year, but there does not appear to be any correlation between policy timing and the magnitude of these asset changes.

Table 5 provides a first set of difference in difference estimates. First, differences in after tax income and expenditure between the treatment group and each of the control groups were recorded for each period. ${ }^{21}$ These are listed under the difference headings. Second, the difference in difference figures were obtained by way of simple subtraction of the base period results from the two policy period estimates. The early policy period marks a drastic decrease in mean net income and in total expenditure of Ontario single mothers relative to single mothers in Quebec and B.C, and relative to the other two Ontario based control groups. This decrease is estimated at 1230 dollars of income, and 1045 dollars of expenditure, relative to single mothers in other provinces. Relative to unmarried single women, the decrease is 469 dollars of income and 637 dollars of expenditure. Relative to married couples, the corresponding figures are 1530 dollars of income and 1321 dollars of expenditure. With exception of results relative to single unmarried women all the estimates of the initial relative fall are significant at $5 \%$ level. These results suggest, that it was not until the post implementation period, that the

\footnotetext{
${ }^{21}$ As shown in the appendix the difference in difference results for wage income, transfer income and change in assets cannot be considered reliable.
} 
relative levels of consumption of Ontario single mothers have at least partially recovered. While the magnitude of the results varies, the overall pattern of initial decline and followed by a recovery repeats across all subsequent specifications.

The early reform period drop in net income and total expenditure, relative to Quebec and B.C. single mothers is significantly below the one relative to Ontario married couples and significantly above the one relative to Ontario single childless women. The estimates for the change relative to Quebec and B.C. single mothers show a nearly complete reversal of the effects of the initial shock. The lack of significance, of late reform difference in difference results, suggest no long-term policy effect. The late reform difference in difference policy effect relative to single unmarried women depends on the choice of the consumption measure; it is positive for net income and negative for total expenditure. The results for married couples with children show only a partial late reform improvement with the net effect being a relative decrease of 728 dollars of expenditure and 641 dollars of income.

\subsection{Regression adjusted difference in difference results}

Two regressions were run in order to further investigate the relative changes in the consumption levels of Ontario single mothers. Tables 6 and 7 describe the results of two sets of regressions. Table 6 uses total per capita family net income as a dependent variable. Table 7 uses, per capita total expenditure measure. The early reform period is associated with a statistically significant fall in the relative consumption levels among Ontario single mothers. The magnitude of this relative decrease ranges from five up to fifteen percent depending on the control group chosen. In the first policy period the 
consumption levels among Ontario single mothers fell by a nearly equal magnitude relative to Ontario married couples with children and to single mothers in Quebec and B.C. This result is difficult to reconcile with what could be expected as a likely policy implication. It should be expected that the consumption levels of groups adversely affected by the policy changes fell the most relative to those who were unaffected. Contrary to this logic, it appears that despite the tightening of the welfare system, the consumption levels among Ontario single mothers fell by similar amounts relative to single mothers outside of Ontario (unaffected by a policy change), as they fell relative to a control group that was affected the most. Thus, the consumption levels among Ontario single mothers fell the most relative to those who, because of their reliance on transfer income, in all likelihood would be the ones most negatively affected by the policy change. $^{22}$

The late reform period results suggest an improvement in comparison with the implementation period. Unlike the early policy results, none of the late policy results are statistically significant at $5 \%$ level. Only the results relative to married couples with children are almost significant at 10\% level. This lack of significance implies no strong long-term policy effect. Apart for their low significance the results suggest that in the late reform period the consumption levels among Ontario single mothers had actually risen relative to Ontario childless single women. The magnitude of the increase is between three and a half and eight percent. Relative to other control groups, the Ontario single mothers' consumption levels increased following the early reform period but

\footnotetext{
${ }^{22}$ A possible explanation for this puzzle is that married couples consist of two individuals who can adjust their employment decisions and that these families are more flexible in their reactions to policy changes than single adult households. Alternatively it could be the case that men in the married couple families face different labor market conditions.
} 
nevertheless remained lower than the pre reform estimates. Relative to Married couples with children, the post policy decrease in consumption levels fluctuate around seven percent.

The marginal effects of the time period treatment interaction dummy variable that summarizes the difference in difference component of the regression results are presented in Table 8. All figures are presented per household member. The results are similar, regardless of whether total expenditure or net income is chosen as the dependent variable. The first panel in table 8 indicates that the net income of Ontario single mothers relative to that of Quebec and B.C. single mothers fell by 1373 dollars, and total expenditure fell by 1396 dollars during the early reform period. Here, the importance of geographically different but otherwise similar control groups needs to be emphasized. Unlike in the case of 'raw' results, these effects are much smaller relative to the other control groups.

The post implementation policy effects are again statistically insignificant. Their magnitudes however consistently point towards a recovery of relative consumption levels among Ontario single mother headed households. As table 8 shows, change during the late reform period, relative to Quebec and B.C. single mothers, turns out to be a decrease of 617 dollars of income and 438 dollars of expenditure per household member. The decrease relative to married couples is about a hundred dollars. Relative to single childless women in Ontario the real income of Ontario single mothers increased by 363 dollars and total expenditure increased by 172 dollars. The early to late policy changes, are much greater when the control group is similar but living in different jurisdictions (single mothers in Quebec and B.C.) than when the inverse is true (single childless women or married couples in Ontario). 


\subsection{Propensity Score Matching difference in difference results.}

The final set of results has been obtained through the implementation of the propensity score matching adjusted difference in difference techniques. As described in the methodology section, subjects within the treatment group were matched to a weighted average of subjects in the control group. The matching was done based on a number of observable characteristics. The variables used to determine propensity scores were age, household size, and a dummy variable for and urban area of residence. In each period, observations in the treatment group were matched to observations in one of the control groups. The average difference in consumption during each period was then calculated. Finally, in order to obtain difference in difference results, the average mean difference during the base period was subtracted from the average mean differences in each of the policy periods. Matching was done over a determined common support range and, therefore, excluded those subjects for whom no suitable match could be found. ${ }^{23}$

Table 9 contains the results of the matched difference in difference experiment. The early reform fall in the total expenditure relative to Quebec and B.C. single mothers is now only 1102 dollars and the fall in net income is 959 dollars. These declines are similar to those for the 'raw' and regression adjusted difference in difference estimates in tables 5 and 8 . The results for the late reform period indicate that the consumption levels among Ontario single mothers have improved by more than can be suggested by regression adjusted procedures. An decrease of just 90 dollars of income and 117 dollars of total expenditure is noted relative to single mothers in Quebec and B.C. The strength of this conclusion however is undermined by low significance of the late reform period matched results. Another way to interpret this result is to argue that the low significance

\footnotetext{
${ }^{23}$ In each case presented more the $95 \%$ of observations were included in the analysis.
} 
of the late reform estimates indicates no long-term policy effects regardless of their magnitude. Arguably this conclusion holds for each control group and across either measure of consumption.

\section{Conclusions.}

This paper looks at the effects of a series of 1995-1998 Ontario welfare reforms on consumption levels among the province’s single mothers. I merge several Canadian Family Expenditure Surveys and Surveys of Household Spending. I use net income and total expenditure as measures of household consumption. Based on available data I divide the timeframe into three periods: the pre reform period (1982-1992), the early reform period (1996-1998), and the late reform period (1998-2000). A two stage difference in difference design is used to evaluate the relative changes in the consumption levels among Ontario single mothers. I compare these treatment group changes to changes in the consumption levels among three different control groups, namely single mothers in Quebec and B.C., single childless women in Ontario and married couples with children in Ontario. The natural experiment is set during the era of widespread welfare reforms in Canada. Consequently, the counterfactual for the experiment is that of less extensive policy changes rather than of absolute policy stability.

I provide three sets of difference in difference estimates. First, I look at changes in mean differences in reported incomes and expenditures. Second, I provide regression adjusted difference in difference results. Finally, I use propensity score matching 
difference in difference estimators in order to eliminate possible sources of bias, resulting from comparing groups with potentially different average characteristics.

Table 10 summarizes the key results discussed in the preceding section. I find that the early reform period had significant negative effects on the consumption levels among Ontario single mothers. Those effects were negative relative to all control groups and remained so across all the difference in difference specifications. This initial impact however, was offset by positive changes in the late reform period. The magnitudes of the late reform results suggest either partial or complete recovery. The low significance of the late reform results reinforces the hypothesis of no long-term policy effects on the consumption levels of Ontario single mothers relative to each of the three groups used for comparison.

The choice of dependent variable matters least when Quebec and B.C. single mothers are used as a control group; the relative changes in net income and total expenditure suggest the same pattern, and are of similar magnitude. When Ontario based control groups are used, an a priori choice of the dependent variable partially affects the conclusions drawn from the experiment.

To my knowledge, the use of control groups from different jurisdictions and the utilization of matching estimators differentiate my approach from previous related work. As shown, I find that both innovations add potential new information on the overall effect of the welfare reform. 


\section{References:}

Baker M., J Gruber and K. Milligan, (2005), “Universal Childcare, Maternal Labor Supply and Family Well-Being”, Working Paper.

Beaulieu N., B, Fortin, J.Y. Duclos, M. Rouleau, (2005, forthcoming), "The Intergenerational Reliance on Social Assistance: Evidence from Canada", Journal of Population Economics.

Browning M. and T. F. Crossley, (2004), “Shocks, Stocks and Socks”, McMaster University, Department of Economics, Working Paper 2003-07.

Burbidge J. B., L Magee. and A. L. Robb, (1988), “Alternative Transformations to handle Extreme Values of the Dependent Variable”, Journal of The American Statistical Association, Vol. 83, No. 401.

Canadian Council of Social Development "Estimated Number of Persons and Cases Receiving Provincial and Municipal Social Assistance, March 31 1998”, Free Statistics.

Canadian Council of Social Development "Estimated Number of People on Welfare by Province and Territory, 1994-1995”, Free Statistics.

Dooley M., S. Gascon, P. Lefebvre and P. Merrigan (2000), "Lone Female Hardship and Welfare Policy in Canada”, Journal of Human Resources, 35,3, 587-602.

Dooley Martin, (1999), “The Evolution of Welfare Participation Among Canadian Lone Mothers from 1973 - 1991", Canadian Journal of Economics, 32,3, 589-612.

Expenditure Surveys Section, (2000), "Note to Former Users of Data From the Family Expenditure Survey”, Income Statistics Division, Statistics Canada 62F0026MIE-00002.

Fortin B., G Lacroix, S. Drolet, (2004), "Welfare Benefits and the Duration of Welfare Spells: Evidence from a Natural Experiment in Canada", Journal of Public Economics, $88,1495-1520$.

Green D. A. and W. P. Warburton, (2004), “Tightening a Welfare System: the Effects of Benefit Denial on Future Welfare Receipt”, Journal of Public Economics, 88, 1471-1493.

Lefebvre P., (2004), “Quebec’s Innovative Early Childhood Education and Care Policy and its Weaknesses.” Policy Options, March, 52-57.

Lemieux T. and K. Milligan, (2004), "Incentive Effects of Social Assistance: A Regression Discontinuity Approach”, NBER, Working Paper 10541. 
Leuven E. and B. Sianesi, (2003), "PSMATCH2: Stata module to perform full Mahalanobis and propensity score matching, common support graphing, and covariate imbalance testing". http://ideas.repec.org/c/boc/bocode/s432001.html .Version 1.2.3.

Meyer B. D. and J. X. Sullivan, (2004), "The Effects of Welfare and Tax Reform: The Material Well-Being of Single Mothers in 1980s and 1990s.”, Journal of Public Economics., vol 88, Issues 7-8, 1387-1420.

Milligan K. and M. Stabile, (2004), "The Integration of Child Tax Credit and Welfare: Evidence from the National Child Benefit Program”, Draft.

National Council of Welfare, (1998) “Profiles of Welfare: Myths and Realities”, Spring.

“National Child Benefit Progress Report 1999”, Minister of Public Works and Government Services Canada, Cat No: MP43-395/1999E.

“Ontario Works Program Overview” (2001), Ministry of Community and Social Services.

Pennock Michael, (2003), “A Researcher’s Guide To Social Assistance Policy In Canada”, Population Health Research Unit Dalhousie University.

Roy F., (2004), “Social Assistance by Province, 1993-2003”, Canadian Economic Observer, November.

Rosenbaum P., and D. Rubin, (1983), "The Central Role of the Propensity Score in Observational Studies for Causal Effects”, Biometrica 70, 41-55.

Sceviour R. and R. Finnie, (2004), "Social Assistance Use: Trends in Incidence, Entry and Exit Rates”, Canadian Economic Observer, August.

Smith J. S. and P. Todd, (2003). “Does Matching Overcome Lalonde’s Critique of Nonexperimental Estimators?”, Draft.

Statistics Canada (1996) Census Data, Dimension Series.

The National Study of Welfare to Work Programs, provincial phase 1 and phase 2 reports http://publish.uwo.ca/ pomfret/wtw/index.html\# . 
Table 1. By province: number of welfare recipients 1995 and 1998.

\begin{tabular}{|c|c|c|c|}
\hline Year & Ontario & Quebec & B.C. \\
\hline 1995 & $1,344,600$ & 802,200 & 374,300 \\
1998 & $1,091,300$ & 725,700 & 297,400 \\
\hline Reduction $^{+}$ & $19 \%$ & $10 \%$ & $21 \%$ \\
\hline
\end{tabular}

${ }^{+}$The reduction is expressed as percentage of the 1995 figures 
Table 2. Group sample sizes, population represented, mean components of budget constraint and mean total expenditure, by year of survey.

\begin{tabular}{|c|c|c|c|c|c|}
\hline Year & Variable & SM Ontario & $\begin{array}{c}\text { SM Que. \& } \\
\text { BC }\end{array}$ & $\begin{array}{l}\text { Single no } \\
\text { child, } \\
\text { Ontario }\end{array}$ & $\begin{array}{l}\text { Married with } \\
\text { Child, } \\
\text { Ontario }\end{array}$ \\
\hline \multirow[t]{8}{*}{1982} & Sample size & 71 & 118 & 164 & 708 \\
\hline & Population size & 78637 & 94609 & 210868 & 801976 \\
\hline & Transfer Income (if $>0$ ) & 2235 & 2839 & 5193 & 733 \\
\hline & Wage Income ( if $>0$ ) & 9311 & 8445 & 23272 & 12264 \\
\hline & Net Income & 8988 & 7958 & 21681 & 11512 \\
\hline & Total Expenditure & 8424 & 7832 & 18210 & 9361 \\
\hline & Change in assets (if $\sim=0$ ) & 157 & -331 & 863 & 1084 \\
\hline & Alimony (if > 0) & 2315 & 1913 & & \\
\hline \multirow[t]{8}{*}{1986} & Sample size & 86 & 122 & 183 & 562 \\
\hline & Population size & 99920 & 105890 & 231460 & 747230 \\
\hline & Transfer Income (if $>0$ ) & 2681 & 3200 & 5735 & 656 \\
\hline & Wage Income ( if > 0) & 7802 & 7754 & 27941 & 13176 \\
\hline & Net Income & 7612 & 7318 & 23462 & 11696 \\
\hline & Total Expenditure & 7710 & 7235 & 19706 & 10326 \\
\hline & Change in assets (if $\sim=0$ ) & -510 & -157 & 2109 & 273 \\
\hline & Alimony (if >0) & 2478 & 1973 & & \\
\hline \multirow[t]{8}{*}{1992} & Sample size & 100 & 106 & 143 & 463 \\
\hline & Population size & 171660 & 146395 & 218829 & 794600 \\
\hline & Transfer Income (if $>0$ ) & 3381 & 2843 & 4533 & 1062 \\
\hline & Wage Income ( if $>0$ ) & 8105 & 8537 & 32497 & 13656 \\
\hline & Net Income & 8687 & 8359 & 24095 & 12250 \\
\hline & Total Expenditure1 & 9460 & 8219 & 20270 & 10493 \\
\hline & Change in assets (if $\sim=0$ ) & -1052 & -400 & 661 & 434 \\
\hline & Alimony (if > 0) & 1933 & 2425 & & \\
\hline \multirow[t]{8}{*}{1996} & Sample size & 70 & 113 & 166 & 429 \\
\hline & Population size & 119344 & 154712 & 247754 & 717704 \\
\hline & Transfer Income (if $>0$ ) & 3539 & 2919 & 5323 & 1117 \\
\hline & Wage Income (if $>0$ ) & 7718 & 10978 & 29030 & 14413 \\
\hline & Net Income & 7632 & 9448 & 22520 & 12513 \\
\hline & Total Expenditure & 7353 & 8585 & 18711 & 9974 \\
\hline & Change in assets (if $\sim=0$ ) & -140 & 309 & 1584 & 1199 \\
\hline & Alimony (if $>0$ ) & 1385 & 2002 & & \\
\hline \multirow[t]{8}{*}{1997} & Sample size & 114 & 235 & 144 & 505 \\
\hline & Population size & 170229 & 197243 & 259994 & 859234 \\
\hline & Transfer Income (if $>0$ ) & 3371 & 2611 & 4636 & 982 \\
\hline & Wage Income (if > 0) & 8756 & 8764 & 30359 & 15638 \\
\hline & Net Income & 7673 & 8140 & 21517 & 12730 \\
\hline & Total Expenditure & 7721 & 8094 & 18218 & 10861 \\
\hline & Change in assets (if $\sim=0$ ) & -685 & -388 & 1424 & 697 \\
\hline & Alimony (if > 0) & 1728 & 1883 & & \\
\hline
\end{tabular}

${ }^{+}$Transfer income refers to total government transfer income

${ }^{++}$Change in assets refers to a yearly net change in assets and liabilities 
Table 2. Cts. Group sample sizes, population represented, mean components of budget constraint and mean total expenditure, by year of survey.

\begin{tabular}{|c|c|c|c|c|c|}
\hline Year & Variable & SM Ontario & $\begin{array}{c}\text { SM Que. \& } \\
\text { BC }\end{array}$ & $\begin{array}{l}\text { Single no } \\
\text { child, } \\
\text { Ontario }\end{array}$ & $\begin{array}{l}\text { Married with } \\
\text { Child, } \\
\text { Ontario } \\
\end{array}$ \\
\hline \multirow[t]{8}{*}{1998} & Sample size & 96 & 188 & 126 & 489 \\
\hline & Population size & 147061 & 186924 & 247142 & 893165 \\
\hline & Transfer Income ( if > 0 ) & 2825 & 2728 & 3262 & 968 \\
\hline & Wage Income (if $>0$ ) & 8122 & 8593 & 30711 & 15784 \\
\hline & Net Income & 8215 & 8220 & 24195 & 12834 \\
\hline & Total Expenditure & 8439 & 7943 & 20713 & 11013 \\
\hline & Change in assets (if $\sim=0$ ) & -845 & -207 & 1325 & 622 \\
\hline & Alimony (if >0) & 1775 & 1971 & & \\
\hline \multirow[t]{8}{*}{1999} & Sample size & 103 & 207 & 130 & 484 \\
\hline & Population size & 177508 & 190903 & 236991 & 835365 \\
\hline & Transfer Income (if $>0$ ) & 2862 & 2816 & 6127 & 1040 \\
\hline & Wage Income (if $>0$ ) & 7404 & 8104 & 34321 & 15684 \\
\hline & Net Income & 8477 & 8445 & 23708 & 12799 \\
\hline & Total Expenditure & 8518 & 8557 & 19767 & 11014 \\
\hline & Change in assets (if $\sim=0$ ) & -477 & -558 & 2787 & 520 \\
\hline & Alimony (if >0) & 1585 & 1952 & & \\
\hline \multirow[t]{8}{*}{2000} & Sample size & 82 & 153 & 122 & 449 \\
\hline & Population size & 175541 & 182962 & 226583 & 862015 \\
\hline & Transfer Income (if $>0$ ) & 2559 & 2549 & 4963 & 907 \\
\hline & Wage Income (if $>0$ ) & 11187 & 8502 & 29068 & 15962 \\
\hline & Net Income & 9407 & 8841 & 21294 & 13384 \\
\hline & Total Expenditure & 9513 & 8417 & 19252 & 11293 \\
\hline & Change in assets (if $\sim=0$ ) & -701 & 36 & 113 & 999 \\
\hline & Alimony (if > 0) & 1413 & 1835 & & \\
\hline \multirow[t]{8}{*}{2001} & Sample size & 74 & 168 & 133 & 489 \\
\hline & Population size & 152616 & 176874 & 224102 & 884209 \\
\hline & Transfer Income (if $>0$ ) & 2397 & 2724 & 4275 & 1039 \\
\hline & Wage Income (if $>0$ ) & 9785 & 8016 & 35943 & 16335 \\
\hline & Net Income & 10107 & 8685 & 24748 & 13561 \\
\hline & Total Expenditure & 10420 & 8469 & 21491 & 11197 \\
\hline & Change in assets (if $\sim=0$ ) & -743 & -360 & 930 & 1117 \\
\hline & Alimony (if > 0) & 2010 & 1699 & & \\
\hline
\end{tabular}


Table 3. Income sources by group and year. Proportion of families reporting selected budget constraint components greater than or not equal to zero. All figures reported in percentage terms.

\begin{tabular}{|c|c|c|c|c|c|c|}
\hline Year & & Variable & SM Ontario & $\begin{array}{c}\text { SM Que. \& } \\
\text { BC }\end{array}$ & $\begin{array}{c}\text { Single no } \\
\text { child, } \\
\text { Ontario } \\
\end{array}$ & $\begin{array}{c}\text { Married with } \\
\text { Child, } \\
\text { Ontario } \\
\end{array}$ \\
\hline \multirow[t]{5}{*}{1982} & \multirow{5}{*}{$\%$ of } & Sample size & 71 & 118 & 164 & 708 \\
\hline & & Transfer Income (if $>0$ ) & 100 & 100 & 41 & 100 \\
\hline & & Wage Income (if > 0) & 72 & 62 & 80 & 96 \\
\hline & & Change in assets (if $\sim=0$ ) & 58 & 62 & 45 & 31 \\
\hline & & Alimony (if > 0) & 41 & 49 & & \\
\hline \multirow[t]{5}{*}{1986} & \multirow{5}{*}{$\%$ of } & Sample size & 86 & 122 & 183 & 562 \\
\hline & & Transfer Income ( if $>0$ ) & 100 & 100 & 36 & 99 \\
\hline & & Wage Income ( if >0 ) & 60 & 53 & 74 & 96 \\
\hline & & Change in assets (if $\sim=0$ ) & 77 & 80 & 45 & 44 \\
\hline & & Alimony (if >0) & 41 & 34 & & \\
\hline \multirow[t]{5}{*}{1992} & \multirow{5}{*}{$\%$ of } & Sample size & 100 & 106 & 143 & 463 \\
\hline & & Transfer Income (if $>0$ ) & 99 & 99 & 63 & 99 \\
\hline & & Wage Income ( if > 0 ) & 64 & 59 & 74 & 96 \\
\hline & & Change in assets (if $\sim=0$ ) & 74 & 70 & 47 & 42 \\
\hline & & Alimony (if $>0$ ) & 37 & 52 & & \\
\hline \multirow[t]{5}{*}{1996} & \multirow{5}{*}{$\%$ of } & Sample size & 70 & 113 & 166 & 429 \\
\hline & & Transfer Income (if > 0 ) & 96 & 94 & 64 & 77 \\
\hline & & Wage Income ( if >0 ) & 54 & 64 & 64 & 93 \\
\hline & & Change in assets (if $\sim=0$ ) & 74 & 60 & 51 & 34 \\
\hline & & Alimony (if $>0$ ) & 39 & 43 & & \\
\hline \multirow[t]{5}{*}{1997} & \multirow{5}{*}{$\%$ of } & Sample size & 114 & 235 & 144 & 505 \\
\hline & & Transfer Income ( if $>0$ ) & 96 & 94 & 69 & 70 \\
\hline & & Wage Income ( if $>0$ ) & 51 & 67 & 70 & 98 \\
\hline & & Change in assets (if $\sim=0$ ) & 68 & 65 & 52 & 39 \\
\hline & & Alimony (if $>0$ ) & 41 & 39 & & \\
\hline \multirow[t]{5}{*}{1998} & \multirow{5}{*}{$\%$ of } & Sample size & 96 & 188 & 126 & 489 \\
\hline & & Transfer Income ( if > 0 ) & 94 & 98 & 60 & 70 \\
\hline & & Wage Income ( if > 0) & 68 & 65 & 80 & 98 \\
\hline & & Change in assets (if $\sim=0$ ) & 76 & 66 & 49 & 40 \\
\hline & & Alimony (if $>0$ ) & 44 & 42 & & \\
\hline \multirow[t]{5}{*}{1999} & \multirow{5}{*}{$\%$ of } & Sample size & 103 & 207 & 130 & 484 \\
\hline & & Transfer Income (if $>0$ ) & 98 & 95 & 57 & 69 \\
\hline & & Wage Income ( if $>0$ ) & 80 & 71 & 72 & 98 \\
\hline & & Change in assets (if $\sim=0$ ) & 61 & 74 & 44 & 43 \\
\hline & & Alimony (if $>0$ ) & 47 & 43 & & \\
\hline \multirow[t]{5}{*}{2000} & \multirow{5}{*}{$\%$ of } & Sample size & 82 & 153 & 122 & 449 \\
\hline & & Transfer Income ( if $>0$ ) & 93 & 95 & 79 & 88 \\
\hline & & Wage Income (if $>0$ ) & 72 & 75 & 71 & 99 \\
\hline & & Change in assets (if $\sim=0$ ) & 55 & 63 & 52 & 42 \\
\hline & & Alimony (if $>0$ ) & 43 & 46 & & \\
\hline \multirow[t]{5}{*}{2001} & \multirow{5}{*}{$\%$ of } & Sample size & 74 & 168 & 133 & 489 \\
\hline & & Transfer Income (if $>0$ ) & 91 & 96 & 65 & 69 \\
\hline & & Wage Income ( if >0) & 78 & 71 & 68 & 98 \\
\hline & & Change in assets (if $\sim=0$ ) & 61 & 59 & 59 & 38 \\
\hline & & Alimony (if > 0) & 43 & 49 & & \\
\hline
\end{tabular}


Table 4. Probit for labor force participation.

\begin{tabular}{|c|c|c|c|c|c|c|c|c|c|c|c|c|c|}
\hline \multirow{3}{*}{\multicolumn{2}{|c|}{ Control group }} & \multicolumn{6}{|c|}{ Probability of participating in LF } & \multicolumn{6}{|c|}{ Probability of working 52 weeks } \\
\hline & & \multicolumn{2}{|c|}{$\begin{array}{c}\text { Quebec \& BC } \\
\text { single mothers }\end{array}$} & \multicolumn{2}{|c|}{$\begin{array}{c}\text { Single Women, } \\
\text { no children Ontario }\end{array}$} & \multicolumn{2}{|c|}{$\begin{array}{c}\text { Married Couples } \\
\text { with Children, Ontario }\end{array}$} & \multicolumn{2}{|c|}{$\begin{array}{c}\text { Quebec \& BC } \\
\text { single mothers }\end{array}$} & \multicolumn{2}{|c|}{$\begin{array}{c}\text { Single Women, } \\
\text { no children Ontario }\end{array}$} & \multicolumn{2}{|c|}{$\begin{array}{c}\text { Married Couples } \\
\text { with Children, Ontario }\end{array}$} \\
\hline & & dF/dx ${ }^{+} F$ & Robust Std. Err'. & $\mathbf{d F} / \mathbf{d x}$ & Robust Std. Err. & $\mathbf{d} \mathbf{F} / \mathbf{d} \mathbf{x}$ & Robust Std. Err. & $\mathrm{dF} / \mathrm{dx}$ & Robust Std. Err. & $\mathrm{dF} / \mathrm{dx}$ & Robust Std. Err. & $\mathbf{d F} / \mathbf{d} \mathbf{x}$ & Robust Std. Err \\
\hline \multirow{3}{*}{$\begin{array}{c}\text { Period } \\
\mathrm{x} \\
\text { Treatmen }\end{array}$} & $\begin{array}{l}\text { Pre reform: } \\
1982,1986,1992\end{array}$ & base & --- & base & --- & base & --- & base & --- & base & --- & base & --- \\
\hline & $\begin{array}{l}\text { Early reform: } \\
1996,1997,1998\end{array}$ & $\star *-0.160$ & 0.060 & $<0.001$ & 0.053 & **0.062 & 0.017 & -0.098 & 0.053 & 0.014 & 0.060 & 0.078 & 0.045 \\
\hline & $\begin{array}{l}\text { Late reform: } \\
\text { 1999, 2000, } 2001\end{array}$ & $\mid-0.068$ & 0.065 & **0.181 & 0.041 & **0.103 & 0.010 & *0.007 & 0.062 & **0.186 & 0.061 & **0.145 & 0.043 \\
\hline \multirow{7}{*}{ Period } & reatment group & $* 0.075$ & 0.042 & $* *-0.208$ & 0.057 & $* *_{-} 0.473$ & 0.039 & 0.039 & 0.044 & $*^{*}-0.192$ & 0.055 & $* *-0.393$ & 0.034 \\
\hline & $\begin{array}{l}\text { Pre reform: } \\
\text { 1982, 1986, } 1992\end{array}$ & base & --- & base & --- & base & --- & base & -- & base & --- & base & --- \\
\hline & $\begin{array}{l}\text { Early reform: } \\
\text { 1996, 1997, } 1998\end{array}$ & 0.040 & 0.037 & $* *-0.084$ & 0.035 & $* *_{-0.141}$ & 0.020 & 0.051 & 0.038 & -0.046 & 0.036 & ${ }^{* *}-0.108$ & 0.021 \\
\hline & $\begin{array}{l}\text { Late reform: } \\
\text { 1999, 2000, } 2001\end{array}$ & $* * 0.092$ & 0.037 & $\star \star-0.133$ & 0.039 & $\star *-0.146$ & 0.021 & 0.041 & 0.039 & $*_{-}-0.084$ & 0.039 & $* *-0.076$ & 0.021 \\
\hline & Age of head & $* * 0.015$ & 0.002 & $*_{-}-0.012$ & 0.001 & $\star * 0.003$ & 0.001 & $* * 0.015$ & 0.002 & ${ }^{* *}-0.006$ & 0.001 & $* * 0.011$ & 0.001 \\
\hline & Household size & $\star *-0.063$ & 0.014 & $* *-0.066$ & 0.020 & $* *-0.025$ & 0.006 & $* *-0.04$ & 0.014 & $*_{-}-0.061$ & 0.022 & $* *_{-} 0.025$ & 0.009 \\
\hline & City Indicator & *0.061 & 0.036 & $* * 0.099$ & 0.038 & 0.019 & 0.015 & $\star * 0.068$ & 0.033 & $\star * 0.100$ & 0.038 & 0.027 & 0.020 \\
\hline
\end{tabular}

${ }^{+}$Apart for age and h-hold size $\mathrm{dF} / \mathrm{dx}$ is for discrete change of dummy variable from 0 to 1

${ }^{++}$Here and thereafter 'Robust' refers to heteroscedasticity consistent White variance estimator.

** significant at $5 \%$ level 
Table 5. 'Raw' difference in difference estimates ${ }^{+}$. All numbers expressed in 1992 dollars.

\begin{tabular}{|c|c|c|c|c|c|}
\hline \multirow[b]{2}{*}{ Control group } & \multirow[b]{2}{*}{ Time period } & \multicolumn{2}{|c|}{ Net income } & \multicolumn{2}{|c|}{ Total expenditure } \\
\hline & & Difference & \begin{tabular}{|c|} 
Difference in \\
difference \\
[std. error]
\end{tabular} & Difference & \begin{tabular}{|l|} 
Difference in \\
difference \\
[std. error]
\end{tabular} \\
\hline $\begin{array}{l}\text { Single mothers } \\
\text { Quebec and B.C. }\end{array}$ & $\begin{array}{c}\text { Pre reform: } \\
\text { 1982, 1986, 1992 } \\
\text { Early reform: } \\
\text { 1996, 1997, 1998 } \\
\text { Late reform: } \\
\text { 1999, 2000, 2001 }\end{array}$ & $\begin{array}{l}546 \\
-684 \\
606\end{array}$ & $\begin{array}{c}--- \\
* *-1230 \\
{[525]} \\
60 \\
{[531]}\end{array}$ & $\begin{array}{l}738 \\
-307 \\
702\end{array}$ & $\begin{array}{c}--- \\
* *-1045 \\
{[469]} \\
-37 \\
{[475]}\end{array}$ \\
\hline $\begin{array}{l}\text { Single women, no } \\
\text { children }\end{array}$ & $\begin{array}{c}\text { Pre reform: } \\
\text { 1982, 1986, } 1992 \\
\text { Early reform: } \\
\text { 1996, 1997, 1998 } \\
\text { Late reform: } \\
1999,2000,2001\end{array}$ & $\begin{array}{l}-14288 \\
-14757 \\
-13666\end{array}$ & $\begin{array}{c}--- \\
-469 \\
{[1182]} \\
622 \\
{[1211]}\end{array}$ & $\begin{array}{l}-10593 \\
-11230 \\
-10783\end{array}$ & $\begin{array}{l}--- \\
-637 \\
{[923]} \\
-190 \\
{[946]}\end{array}$ \\
\hline $\begin{array}{l}\text { Married couples with } \\
\text { children }\end{array}$ & $\begin{array}{c}\text { Pre reform: } \\
\text { 1982, 1986, } 1992 \\
\text { Early reform: } \\
\text { 1996, 1997, 1998 } \\
\text { Late reform: } \\
1999,2000,2001\end{array}$ & $\begin{array}{l}-3303 \\
-4833 \\
-4032\end{array}$ & $\begin{array}{c}--- \\
* *-1530 \\
{[530]} \\
-728 \\
{[538]}\end{array}$ & $\begin{array}{l}-2659 \\
-1979\end{array}$ & $\begin{array}{c}--- \\
\text { **-1321 } \\
{[401]} \\
-641 \\
{[408]}\end{array}$ \\
\hline
\end{tabular}

+ The first columns under net income and total expenditure respectively describe the average difference between the treatment and the relevant control groups within each period. For example: during the late policy period Ontario single mothers on average reported net incomes 606 dollars higher than Quebec and B.C. single mothers. The second columns under net income and total expenditure summarize the average difference in difference result. For example: relative to Quebec and B.C. single mothers the average net income of Ontario single mothers increased by 60 dollars between the pre reform period and the late reform period.

** significant at $5 \%$ level 
Table 6. Net Income Regression. (inv sinh)

\begin{tabular}{|c|c|c|c|c|c|c|c|}
\hline \multirow{2}{*}{\multicolumn{2}{|c|}{ control groups: }} & \multicolumn{2}{|c|}{$\begin{array}{l}\text { Quebec \& BC } \\
\text { single mothers }\end{array}$} & \multicolumn{2}{|c|}{$\begin{array}{c}\text { Single Women, } \\
\text { no children Ontario }\end{array}$} & \multicolumn{2}{|c|}{$\begin{array}{c}\text { Married Couples } \\
\text { with Children, Ontario }\end{array}$} \\
\hline & & Coef & Robust Std. Err. & Coef & Robust Std. Err. & Coef & Robust Std. Err. \\
\hline \multirow{3}{*}{ Period ${ }^{\star} \mathrm{SM}$} & $\begin{array}{l}\text { Pre reform: } \\
19821986 \\
1992\end{array}$ & base & --- & base & --- & base & --- \\
\hline & $\begin{array}{l}\text { Early reform: } \\
1996,1997,1998\end{array}$ & $* *-0.133$ & 0.050 & -0.050 & 0.058 & $* *-0.128$ & 0.043 \\
\hline & $\begin{array}{l}\text { Late reform: } \\
\text { 1999, 2000, } 2001\end{array}$ & -0.054 & 0.055 & 0.073 & 0.067 & -0.073 & 0.049 \\
\hline \multicolumn{2}{|c|}{ Treatment group dummy } & $* * 0.086$ & 0.035 & ${ }^{* *}-0.547$ & 0.055 & ${ }^{* *}-0.642$ & 0.030 \\
\hline \multirow{3}{*}{ Period } & $\begin{array}{l}\text { Pre reform: } \\
\text { 1982, 1986, } 1992\end{array}$ & base & --- & base & -- & base & --- \\
\hline & $\begin{array}{l}\text { Early reform: } \\
\text { 1996, 1997, } 1998\end{array}$ & -0.042 & 0.032 & ${ }^{* *}-0.118$ & 0.041 & -0.013 & 0.018 \\
\hline & $\begin{array}{l}\text { Late reform: } \\
\text { 1999, 2000, } 2001\end{array}$ & -0.042 & 0.032 & $* *_{-} 0.127$ & 0.048 & 0.027 & 0.019 \\
\hline \multicolumn{2}{|c|}{ Age of head } & $* * 0.024$ & 0.002 & 0.001 & 0.001 & $* * 0.014$ & 0.001 \\
\hline \multicolumn{2}{|c|}{ Household size } & $*_{-0}-0.232$ & 0.013 & $* *_{-0} 0.242$ & 0.021 & ${ }^{* *}-0.234$ & 0.008 \\
\hline \multicolumn{2}{|c|}{ City indicator } & **0.119 & 0.032 & **0.180 & 0.040 & $* * 0.072$ & 0.018 \\
\hline \multicolumn{2}{|c|}{ Constant } & $* \star 9.284$ & 0.070 & **10.701 & 0.076 & $\star * 10.379$ & 0.053 \\
\hline
\end{tabular}

** significant at 5\% level 
Table 7. Total Expenditure Regression. (inv sinh)

\begin{tabular}{|c|c|c|c|c|c|c|c|}
\hline \multicolumn{2}{|c|}{ control groups: } & \multicolumn{2}{|c|}{$\begin{array}{c}\text { Quebec \& BC } \\
\text { single mothers }\end{array}$} & \multicolumn{2}{|c|}{$\begin{array}{c}\text { Single Women, } \\
\text { no children Ontario }\end{array}$} & \multicolumn{2}{|c|}{$\begin{array}{c}\text { Married Couples } \\
\text { with Children, Ontario }\end{array}$} \\
\hline & & Coef & Robust Std. Err. & Coef & Robust Std. Err. & Coef & Robust Std. Err. \\
\hline \multirow{3}{*}{ Period $* S M$} & Pre reform: & base & --- & base & --- & base & --- \\
\hline & $\begin{array}{l}\text { Early reform: } \\
\text { 1996, 1997, } 1998\end{array}$ & $* *_{-0.137}$ & 0.049 & $*_{-0.097}$ & 0.052 & ${ }^{* *}-0.148$ & 0.041 \\
\hline & $\begin{array}{l}\text { Late reform: } \\
\text { 1999, 2000, } 2001\end{array}$ & -0.038 & 0.051 & 0.035 & 0.059 & -0.068 & 0.044 \\
\hline \multicolumn{2}{|c|}{ Treatment group dummy } & $* * 0.130$ & 0.036 & $* *_{-0.383}$ & 0.053 & $*_{-0.431}$ & 0.030 \\
\hline \multirow{3}{*}{ Period } & $\begin{array}{l}\text { Pre reform: } \\
\text { 1982, 1986, } 1992\end{array}$ & base & --- & base & --- & base & --- \\
\hline & $\begin{array}{l}\text { Early reform: } \\
\text { 1996, 1997, } 1998\end{array}$ & -0.028 & 0.031 & -0.046 & 0.034 & $<0.001$ & 0.016 \\
\hline & $\begin{array}{l}\text { Late reform: } \\
\text { 1999, 2000, } 2001\end{array}$ & -0.005 & 0.031 & -0.027 & 0.040 & $* * 0.057$ & 0.016 \\
\hline \multicolumn{2}{|c|}{ Age of head } & **0.018 & 0.001 & $*_{-0.002}$ & 0.001 & $* * 0.009$ & 0.001 \\
\hline \multicolumn{2}{|c|}{ Household size } & $* *-0.227$ & 0.012 & $* *-0.248$ & 0.020 & $* *_{-0.213}$ & 0.008 \\
\hline \multicolumn{2}{|c|}{ City indicator } & $\star * 0.066$ & 0.032 & $\star * 0.085$ & 0.036 & $\star * 0.060$ & 0.016 \\
\hline \multicolumn{2}{|c|}{ Constant } & $\star \star 9.491$ & 0.064 & **10.735 & 0.065 & **10.346 & 0.047 \\
\hline
\end{tabular}

** significant at 5\% level

* significant at $10 \%$ level 
Table 8. Difference in difference regression adjusted results - marginal effects of treatment interaction dummies for the early and late policy periods. All numbers expressed in 1992 dollars.

\begin{tabular}{|c|c|c|c|}
\hline Control groups & Time period & Net income & $\begin{array}{c}\text { Total } \\
\text { expenditure }\end{array}$ \\
\hline $\begin{array}{c}\text { Single mothers } \\
\text { Quebec and B.C. }\end{array}$ & $\begin{array}{c}\text { Early reform: } \\
1996,1997,1998 \\
\text { Late reform: } \\
1999,2000,2001\end{array}$ & -617 & -438 \\
\hline $\begin{array}{c}\text { Early reform: } \\
\text { Single women, no } \\
\text { children }\end{array}$ & $\begin{array}{c}1996,1997,1998 \\
\text { Late reform: } \\
1999,2000,2001\end{array}$ & -199 & $*_{-}-377$ \\
\hline $\begin{array}{c}\text { Early reform: } \\
\text { Married couples with } \\
\text { children }\end{array}$ & $\begin{array}{c}1996,1997,1998 \\
\text { Late reform: } \\
1999,2000,2001\end{array}$ & -127 & -172 \\
\hline
\end{tabular}

Each number represents a change in average differences between the treatment group and the control groups. For example: relative to Quebec and B.C. single mothers the average net income of Ontario single mothers fell by 1373 dollars between the pre reform period and the early reform period.

** indicates a marginal effect, when the difference in difference coefficient is significant at $5 \%$ level

* indicates a marginal effect, when the difference in difference coefficient is significant $10 \%$ level 
Table 9. Difference in difference propensity score adjusted matching estimates. Matching on propensity score from a logistic regression on presence in the treatment group. Epanechnikov Kernel matching. All numbers expressed in 1992 dollars.

\begin{tabular}{|c|c|c|c|c|c|}
\hline \multirow[b]{2}{*}{ Control groups } & \multirow[b]{2}{*}{ Time period } & \multicolumn{2}{|c|}{ Net income } & \multicolumn{2}{|c|}{ Total expenditure } \\
\hline & & Difference & $\begin{array}{l}\text { Difference in } \\
\text { difference. }\end{array}$ & Difference & $\begin{array}{l}\text { Difference in } \\
\text { difference. }\end{array}$ \\
\hline \multirow{3}{*}{$\begin{array}{l}\text { Single mothers } \\
\text { Quebec and B.C. }\end{array}$} & $\begin{array}{c}\text { Pre reform: } \\
1982,1986,1992\end{array}$ & 623 & --- & 809 & --- \\
\hline & $\begin{array}{c}\text { Early reform: } \\
1996,1997,1998\end{array}$ & -478 & $\begin{array}{l}* *-1102 \\
{[438]}\end{array}$ & -150 & $\begin{array}{l}* *-959 \\
{[448]}\end{array}$ \\
\hline & $\begin{array}{l}\text { Late reform: } \\
1999,2000,2001\end{array}$ & 533 & $\begin{array}{l}-90 \\
{[547]}\end{array}$ & 692 & $\begin{array}{l}-117 \\
{[560]}\end{array}$ \\
\hline \multirow{3}{*}{$\begin{array}{l}\text { Single women, no } \\
\text { children }\end{array}$} & $\begin{array}{c}\text { Pre reform: } \\
1982,1986,1992\end{array}$ & -14997 & --- & -11803 & --- \\
\hline & $\begin{array}{c}\text { Early reform: } \\
1996,1997,1998\end{array}$ & -16905 & $\begin{array}{l}{ }_{-}^{*}-1908 \\
{[1472]}\end{array}$ & -12518 & $\begin{array}{l}-716 \\
{[904]}\end{array}$ \\
\hline & $\begin{array}{c}\text { Late reform: } \\
1999,2000,2001\end{array}$ & -15751 & $\begin{array}{c}-754 \\
{[1452]}\end{array}$ & -12288 & $\begin{array}{c}-486 \\
{[1054]}\end{array}$ \\
\hline \multirow{3}{*}{$\begin{array}{l}\text { Married couples with } \\
\text { children }\end{array}$} & $\begin{array}{c}\text { Pre reform: } \\
1982,1986,1992\end{array}$ & -6942 & -- & -4193 & -- \\
\hline & $\begin{array}{c}\text { Early reform: } \\
1996,1997,1998\end{array}$ & -7595 & $\begin{array}{l}-652 \\
{[514]}\end{array}$ & -5179 & $\begin{array}{c}* *_{-} 986 \\
{[445]}\end{array}$ \\
\hline & $\begin{array}{c}\text { Late reform: } \\
1999,2000,2001\end{array}$ & -6602 & $\begin{array}{c}340 \\
{[548]}\end{array}$ & -4408 & $\begin{array}{l}-215 \\
{[526]}\end{array}$ \\
\hline
\end{tabular}

The first columns under net income and total expenditure respectively describe the average difference between the treatment and the relevant control groups within each period. For example: during the late policy period Ontario single mothers on average reported net incomes 533 dollars higher than Quebec and B.C. single mothers. The second columns under net income and total expenditure summarize the average difference in difference result. For example: relative to Quebec and B.C. single mothers the average net income of Ontario single mothers decreased by 90 dollars between the pre reform period and the late reform period.

** significant at 5\% level

* significant at $10 \%$ level 
Table 10. Summary of difference in difference results form tables 5, 8 and 9.

\begin{tabular}{|c|c|c|c|c|c|c|c|}
\hline \multirow{2}{*}{ Control groups } & \multirow{2}{*}{ Time period } & \multicolumn{2}{|c|}{ Raw } & \multicolumn{2}{|c|}{$\begin{array}{l}\text { Regression } \\
\text { adjusted }\end{array}$} & \multicolumn{2}{|c|}{$\begin{array}{c}\text { Propensity score matching } \\
\text { adjusted }\end{array}$} \\
\hline & & $\begin{array}{c}\text { Net } \\
\text { Income }\end{array}$ & $\begin{array}{c}\text { Total } \\
\text { Expenditure }\end{array}$ & $\begin{array}{c}\text { Net } \\
\text { Income }\end{array}$ & $\begin{array}{c}\text { Total } \\
\text { Expenditure }\end{array}$ & $\begin{array}{c}\text { Net } \\
\text { Income }\end{array}$ & $\begin{array}{c}\text { Total } \\
\text { Expenditure }\end{array}$ \\
\hline \multirow{2}{*}{$\begin{array}{l}\text { Single mothers } \\
\text { Quebec and B.C. }\end{array}$} & $\begin{array}{c}\text { Early reform: } \\
1996,1997,1998\end{array}$ & $* *-1230$ & $* *-1045$ & **-1373 & **-1396 & **-1102 & **_959 \\
\hline & $\begin{array}{c}\text { Late reform: } \\
1999,2000,2001\end{array}$ & 60 & -37 & -617 & -438 & -90 & -117 \\
\hline \multirow{2}{*}{$\begin{array}{l}\text { Single women, no } \\
\text { children }\end{array}$} & $\begin{array}{c}\text { Early reform: } \\
1996,1997,1998\end{array}$ & -469 & -637 & -199 & *-377 & *-1908 & -716 \\
\hline & $\begin{array}{c}\text { Late reform: } \\
1999,2000,2001\end{array}$ & 622 & -190 & 363 & 172 & -754 & -486 \\
\hline \multirow{2}{*}{$\begin{array}{l}\text { Married couples with } \\
\text { children }\end{array}$} & $\begin{array}{c}\text { Early reform: } \\
1996,1997,1998\end{array}$ & $* *-1530$ & $* *-1321$ & $* *-183$ & $* *-209$ & -652 & **_986 \\
\hline & $\begin{array}{l}\text { Late reform: } \\
1999,2000,2001\end{array}$ & -728 & -641 & -127 & -118 & 340 & -215 \\
\hline
\end{tabular}

** significant at 5\% level

* significant at $10 \%$ level 
Appendix 1. A look at various components of the budget constraint - a regression adjusted difference in difference approach. Will be made available on internet.

Tables A1, A2 and A3 contain results of regressions on government transfer income, wage income, and net yearly change in assets and liabilities respectively. The magnitude of several of these interaction terms and of the dummy variable coefficients is implausible. 
Table A1. Government Transfer Income regression (inverse sinh) Will be made available on internet.

\begin{tabular}{|c|c|c|c|c|c|c|}
\hline \multirow[t]{2}{*}{ Control groups: } & \multicolumn{2}{|c|}{$\begin{array}{l}\text { Quebec \& BC } \\
\text { single mothers }\end{array}$} & \multicolumn{2}{|c|}{$\begin{array}{c}\text { Single Women, } \\
\text { no children Ontario }\end{array}$} & \multicolumn{2}{|c|}{$\begin{array}{c}\text { Married Couples } \\
\text { with Children, Ontario }\end{array}$} \\
\hline & Coef & Robust Std. Err. & Coef & Robust Std. Err. & Coef & Robust Std. Err. \\
\hline $\begin{array}{l}\text { Pre reform: } \\
\text { 1982, 1986, } 1992\end{array}$ & base & --- & base & --- & base & --- \\
\hline $\begin{array}{l}\text { Period*SM Early reform: } \\
1996,1997,1998\end{array}$ & 0.319 & 0.186 & **-1.014 & 0.330 & **1.728 & 0.180 \\
\hline $\begin{array}{l}\text { Late reform: } \\
\text { 1999, 2000, } 2001\end{array}$ & *0.092 & 0.197 & **-1.541 & 0.356 & $* \star 1.268$ & 0.184 \\
\hline Treatment group dummy & $*_{-0.188}$ & 0.107 & $\star * 4.497$ & 0.282 & **1.468 & 0.104 \\
\hline $\begin{array}{l}\text { Pre reform: } \\
\text { 1982, 1986, } 1992\end{array}$ & base & --- & base & --- & base & --- \\
\hline $\begin{array}{ll}\text { Period } & \text { Early reform: } \\
& 1996,1997,1998\end{array}$ & $* *-0.231$ & 0.108 & **1.172 & 0.285 & $* *-1.688$ & 0.103 \\
\hline $\begin{array}{l}\text { Late reform: } \\
1999,2000,2001\end{array}$ & *-0.194 & 0.115 & **1.288 & 0.313 & $* *-1.416$ & 0.101 \\
\hline Age of head & $* *-0.072$ & 0.007 & $* * 0.078$ & 0.008 & $* *-0.069$ & 0.006 \\
\hline Household size & 0.072 & 0.048 & 0.103 & 0.082 & $* * 0.236$ & 0.045 \\
\hline City indicator & $* *-0.310$ & 0.104 & $* *-0.975$ & 0.258 & $* *-0.198$ & 0.097 \\
\hline Constant & **10.709 & 0.266 & $\star \star 1.236$ & 0.452 & $\star \star 8.459$ & 0.266 \\
\hline
\end{tabular}

Table A2. Wage Income Regression. (inv sinh) Will be made available on internet.

\begin{tabular}{|c|c|c|c|c|c|c|c|}
\hline \multirow{2}{*}{\multicolumn{2}{|c|}{ Control groups: }} & \multicolumn{2}{|c|}{$\begin{array}{l}\text { Quebec \& BC } \\
\text { single mothers }\end{array}$} & \multicolumn{2}{|c|}{$\begin{array}{c}\text { Single Women, } \\
\text { no children Ontario }\end{array}$} & \multicolumn{2}{|c|}{$\begin{array}{c}\text { Married Couples } \\
\text { with Children, Ontario }\end{array}$} \\
\hline & & Coef & Robust Std. Err. & Coef & Robust Std. Err. & Coef & Robust Std. Err. \\
\hline \multirow{3}{*}{\multicolumn{2}{|c|}{$\begin{aligned} & \text { Period*SM } \text { Early reform: } \\
& \text { 1996, 1997, } 1998 \\
& \text { Late reform: } \\
& 1999,2000,2001 \\
&\end{aligned}$}} & base & --- & base & --- & base & --- \\
\hline & & $\mid * *-1.435$ & 0.515 & -0.276 & 0.532 & *-0.737 & 0.419 \\
\hline & & -0.413 & 0.526 & **1.931 & 0.565 & *0.812 & 0.429 \\
\hline \multirow{8}{*}{$\begin{array}{r}\text { Trea } \\
\text { Period }\end{array}$} & tment group dummy & $* * 0.775$ & 0.386 & **-1.927 & 0.519 & $\star *-4.299$ & 0.313 \\
\hline & $\begin{array}{l}\text { Pre reform: } \\
\text { 1982, 1986, } 1992\end{array}$ & base & --- & base & --- & base & --- \\
\hline & $\begin{array}{l}\text { Early reform: } \\
\text { 1996, 1997, } 1998\end{array}$ & 0.392 & 0.342 & $*_{-0.564}$ & 0.305 & 0.138 & 0.084 \\
\hline & $\begin{array}{l}\text { Late reform: } \\
\text { 1999, 2000, } 2001\end{array}$ & $* \star 0.873$ & 0.338 & **-0.833 & 0.352 & **0.326 & 0.081 \\
\hline & Age of head & $* * 0.174$ & 0.015 & $*^{*}-0.114$ & 0.009 & $* * 0.034$ & 0.007 \\
\hline & Household size & $* *_{-}-0.728$ & 0.120 & ${ }^{*} *_{-}-0.847$ & 0.200 & $\star *-0.448$ & 0.053 \\
\hline & City indicator & $* * 0.814$ & 0.304 & $* * 1.296$ & 0.339 & $\star * 0.258$ & 0.089 \\
\hline & Constant & 0.571 & 0.679 & $\star \star \star 13.093$ & 0.539 & **9.914 & 0.307 \\
\hline
\end{tabular}


Table A3. Yearly Net Change in Assets and liabilities regression. (inv sinh) Will be made available on internet.

\begin{tabular}{|c|c|c|c|c|c|c|}
\hline \multirow[t]{2}{*}{ Control groups: } & \multicolumn{2}{|c|}{$\begin{array}{l}\text { Quebec \& BC } \\
\text { single mothers }\end{array}$} & \multicolumn{2}{|c|}{$\begin{array}{c}\text { Single Women, } \\
\text { no children Ontario }\end{array}$} & \multicolumn{2}{|c|}{$\begin{array}{c}\text { Married Couples } \\
\text { with Children, Ontario } \\
\end{array}$} \\
\hline & Coef & Robust Std. Err. & Coef & Robust Std. Err. & Coef & Robust Std. Err. \\
\hline $\begin{array}{l}\text { Pre reform: } \\
\text { 1982, 1986, } 1992\end{array}$ & base & --- & base & --- & base & --- \\
\hline $\begin{array}{l}\text { Period*SM Early reform: } \\
1996,1997,1998\end{array}$ & -0.891 & 0.729 & $* * 1.566$ & 0.792 & 0.523 & 0.629 \\
\hline $\begin{array}{l}\text { Late reform: } \\
\text { 1999, 2000, } 2001\end{array}$ & 0.477 & 0.813 & **2.587 & 0.880 & $* \star 1.834$ & 0.710 \\
\hline Treatment group dummy & -0.343 & 0.559 & $* *-4.410$ & 0.749 & $\star *-4.656$ & 0.494 \\
\hline $\begin{array}{l}\text { Pre reform: } \\
\text { 1982, 1986, } 1992\end{array}$ & base & --- & base & --- & base & --- \\
\hline $\begin{array}{ll}\text { Period } & \text { Early reform: } \\
& 1996,1997,1998\end{array}$ & **1.312 & 0.485 & *-0.987 & 0.576 & 0.206 & 0.310 \\
\hline $\begin{array}{l}\text { Late reform: } \\
1999,2000,2001\end{array}$ & *0.912 & 0.497 & -0.912 & 0.617 & -0.136 & 0.314 \\
\hline Age of head & $* * 0.057$ & 0.021 & -0.018 & 0.016 & $\star * 0.057$ & 0.016 \\
\hline Household size & -0.242 & 0.174 & 0.069 & 0.260 & -0.461 & 0.132 \\
\hline City indicator & $* * 0.982$ & 0.436 & 0.880 & 0.541 & $* * 0.245$ & 0.301 \\
\hline Constant & $* *-3.837$ & 0.987 & $\star \star 1.957$ & 0.960 & **1.456 & 0.785 \\
\hline
\end{tabular}




\section{Appendix 2: Extensions of initial results - a look at various components of total expenditure. Regression adjusted difference in difference approach. Will be made}

\section{available on internet.}

This section looks at how the consumption patterns of lower income single mothers differed from the mean estimates. The output of bootstrapped quintile regressions ${ }^{24}$ on the $25^{\text {th }}$ percentile of net income and expenditure distributions is summarized in tables A4 and A5 summarize respectively. These results indicate that the early reform relative fall in the net income and total expenditure of Ontario single mothers was less severe at the $25^{\text {th }}$ percentile of income or expenditure distributions than at their respective means. This finding is potentially important given the previously suggested trend of a proportion of Ontario single mothers dropping out of the labor force in response to the early reforms and returning only during the late reform period. This result, combined with information from the tables 2 and 3 in the main body of the paper, indicates that the relative fall in the early reform period in the Ontario single mother consumption levels was more severe among those whose major source of income was wages and not social transfers.

Tables A6 and A7 summarize regression output when per capita expenditure on durables and on necessities respectively are used as the dependent variable. Similarly to Browning and Crossley (2004), I find that expenditure on durables ${ }^{25}$ decreased more

\footnotetext{
${ }^{24} 200$ repetitions each.

${ }^{25}$ Durables are defined as the sum of expenditures on furnishings, car purchases and clothing.
} 
significantly than the overall expenditure in response to the negative income shock. Table A6 shows that during the early reform period, relative expenditure on durables decreased by 26 to 50 percent depending on the control group. These numbers are significantly larger than those reported for total expenditure. In times of negative financial shock, Ontario single mothers responded with delaying the purchases of goods that were not of immediate need. This hypothesis is further reinforced by the results indicated in table A7. A regression on necessities ${ }^{26}$ reveals that the relative household response was much lower, and that there was no long term policy effect.

\footnotetext{
${ }^{26}$ Necessities are defined as the sum of food at home, household operation and clothing
} 
Table A4. Bootstrapped Quintile regression, 25\% percentile of income, 200 repetitions.

Will be made available on internet.

\begin{tabular}{|c|c|c|c|c|c|c|c|}
\hline \multicolumn{2}{|c|}{ Control groups: } & \multicolumn{2}{|c|}{$\begin{array}{c}\text { Quebec \& BC } \\
\text { single mothers }\end{array}$} & \multicolumn{2}{|c|}{$\begin{array}{c}\text { Single Women, } \\
\text { no children Ontario }\end{array}$} & \multicolumn{2}{|c|}{$\begin{array}{c}\text { Married Couples } \\
\text { with Children, Ontario }\end{array}$} \\
\hline & & Coef & Robust Std. Err. & Coef & Robust Std. Err & Coef & Robust Std. Err. \\
\hline \multirow{2}{*}{\multicolumn{2}{|c|}{\begin{tabular}{|c|} 
Pre reform: \\
1982, 1986, 1992 \\
Early reform: \\
Period*SM $1996,1997,1998$
\end{tabular}}} & base & --- & base & --- & base & --- \\
\hline & & $*-0.094$ & 0.050 & 0.009 & 0.093 & $* *-0.082$ & 0.041 \\
\hline & $\begin{array}{l}\text { Late reform: } \\
1999,2000,2001\end{array}$ & $\mid-0.054$ & 0.059 & 0.118 & 0.092 & -0.029 & 0.056 \\
\hline \multicolumn{2}{|c|}{ Treatment group dummy } & $*_{0.065}$ & 0.039 & $*_{-0.514}$ & 0.077 & $* *-0.715$ & 0.035 \\
\hline \multirow{3}{*}{ Period } & $\begin{array}{l}\text { Pre reform: } \\
1982,1986,1992\end{array}$ & base & --- & base & --- & base & --- \\
\hline & $\begin{array}{l}\text { Early reform: } \\
\text { 1996, 1997, } 1998\end{array}$ & -0.025 & 0.033 & *-0.155 & 0.083 & $*_{-0.034}$ & 0.018 \\
\hline & $\begin{array}{l}\text { Late reform: } \\
\text { 1999, 2000, } 2001\end{array}$ & $\mid-0.004$ & 0.035 & ** -0.203 & 0.077 & -0.013 & 0.024 \\
\hline \multicolumn{2}{|c|}{ Age of head } & $\star \star 0.016$ & 0.002 & -0.001 & 0.002 & $* * 0.012$ & 0.001 \\
\hline \multicolumn{2}{|c|}{ Household size } & $* *-0.197$ & 0.010 & $*_{-}^{*} 0.211$ & 0.016 & $* *-0.210$ & 0.009 \\
\hline \multirow{2}{*}{\multicolumn{2}{|c|}{$\begin{array}{l}\text { City indicator } \\
\text { Constant }\end{array}$}} & $\star * 0.087$ & 0.029 & **0.172 & 0.064 & $\star * 0.076$ & 0.019 \\
\hline & & $* \star 9.176$ & 0.061 & $* \star 10.333$ & 0.112 & **10.162 & 0.053 \\
\hline
\end{tabular}

Table A5. Bootstrapped Quintile regression, 25\% percentile of expenditure, 200 repetitions. Will be made available on internet.

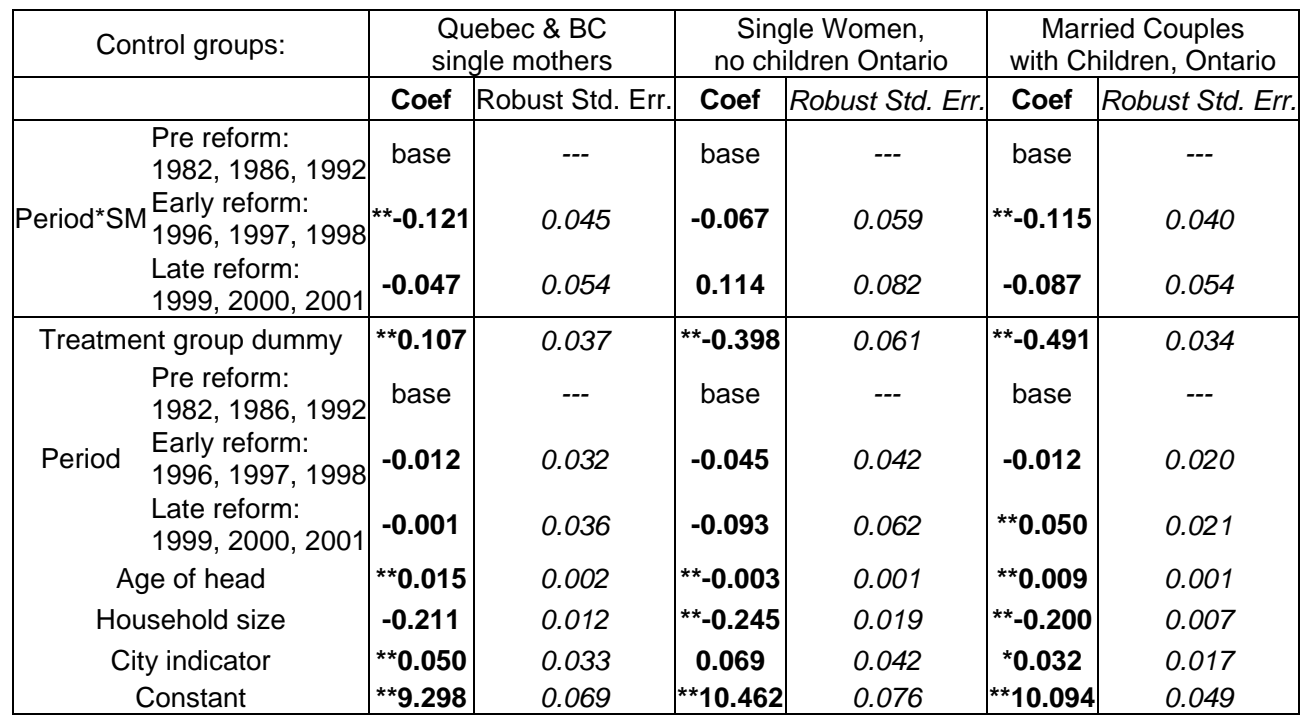


Table A6. Durable Expenditure Regression (furnishings, car purchase and clothing). Will be made available on internet.

\begin{tabular}{|c|c|c|c|c|c|c|}
\hline \multirow[t]{2}{*}{ Control groups: } & \multicolumn{2}{|c|}{$\begin{array}{l}\text { Quebec \& BC } \\
\text { single mothers }\end{array}$} & \multicolumn{2}{|c|}{$\begin{array}{c}\text { Single Women, } \\
\text { no children Ontario }\end{array}$} & \multicolumn{2}{|c|}{$\begin{array}{c}\text { Married Couples } \\
\text { with Children, Ontario }\end{array}$} \\
\hline & Coef & Robust Std. Err. & Coef & Robust Std. Err. & Coef & Robust Std. Err. \\
\hline $\begin{array}{l}\text { Pre reform: } \\
\text { 1982, 1986, } 1992\end{array}$ & base & --- & base & --- & base & --- \\
\hline 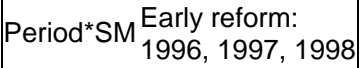 & $* *-0.498$ & 0.169 & -0.270 & 0.178 & $* *-0.287$ & 0.131 \\
\hline $\begin{array}{l}\text { Late reform: } \\
\text { 1999, 2000, 2001 }\end{array}$ & -0.230 & 0.169 & 0.040 & 0.184 & -0.140 & 0.131 \\
\hline Treatment group dummy & $* * 0.407$ & 0.118 & $* *_{-0} .472$ & 0.148 & $* *-0.463$ & 0.081 \\
\hline $\begin{array}{l}\text { Pre reform: } \\
\text { 1982, 1986, } 1992\end{array}$ & base & --- & base & --- & base & --- \\
\hline $\begin{array}{ll}\text { Period } & \text { Early reform: } \\
& 1996,1997,1998\end{array}$ & -0.199 & 0.127 & **-0.354 & 0.129 & $* *-0.328$ & 0.063 \\
\hline $\begin{array}{l}\text { Late reform: } \\
\text { 1999, 2000, } 2001\end{array}$ & -0.093 & 0.124 & $*_{-}=0.236$ & 0.142 & -0.079 & 0.052 \\
\hline Age of head & $* * 0.022$ & 0.006 & ${ }^{* *}-0.014$ & 0.004 & *0.007 & 0.004 \\
\hline Household size & $\star \star-0.151$ & 0.033 & $* *_{-}-0.204$ & 0.046 & $* *_{-} 0.168$ & 0.026 \\
\hline City indicator & 0.101 & 0.088 & 0.047 & 0.101 & -0.043 & 0.044 \\
\hline Constant & **6.777 & 0.242 & **9.029 & 0.184 & **8.254 & 0.169 \\
\hline
\end{tabular}

Table A7. Expenditure on Necessities Regression (food at home, household operation and clothing). Will be made available on internet.

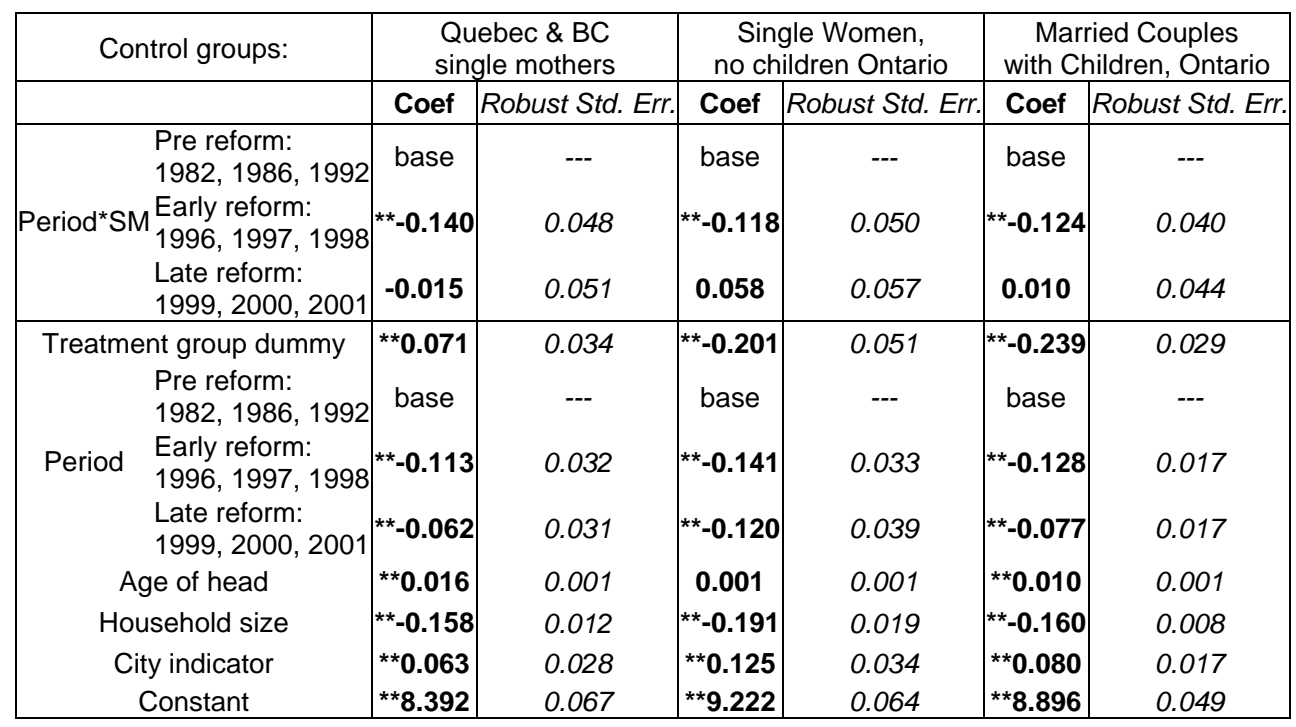

